V. 12 N. 1

JAN-ABR 2016

ISSN 2317-6172

Recebido: 19.02.2014

Aprovado: 10.09.2015

DOI: http://dx.doi.org/10.1590/ 2317-6172201603

1 Escola de Administração de Empresas de São Paulo da Fundação Getulio Vargas São Paulo - SP - Brasil

2 Escola de Administração de Empresas de São Paulo da Fundação Getulio Vargas São Paulo - SP - Brasil

2 Fórum Brasileiro de Segurança Pública São Paulo - SP - Brasil

\section{Estado, polícias e segurança pública no Brasil}

STATE, POLICE AND PUBLIC SAFETY IN BRAZIL

\author{
Renato Sérgio de Lima', Samira Bueno² e Guaracy Mingardi
}

\section{Resumo}

Este texto tem por objetivo associar o debate teórico e acadêmico ao panorama da segurança pública no Brasil, destacando pontos da agenda da área que seriam prioritários para o debate público, ainda mais num momento em que uma nova e inesperada variável entra em campo e precisa ser considerada; qual seja, as demandas difusas que marcam os protestos e as manifestações sociais que tomaram as ruas das principais cidades brasileiras em 2013. 0 artigo propõe que os problemas da área sejam encaminhados a partir de reformas estruturais da arquitetura institucional que regula o funcionamento da segurança pública no Brasil, entendidas como a construção de elos de articulação entre a adoção de medidas incrementais de modernização da gestão da atividade das polícias e a defesa de mudanças legislativas mais substantivas.

\section{Palavras-chave}

Segurança pública; Brasil; reformas estruturais; polícias; violência.

\section{Abstract}

This paper seeks to associate the theoretical and academic debate to the public safety overview in Brazil, highlighting agenda items of the area that would be a priority for the public debate, especially in a moment when a new and unexpected variable enters the field and needs to be considered, namely, diffuse demands that marked the social protests and demonstrations that took the streets of major Brazilian cities in 2013. The article proposes that the problems of the area are better directed from structural reforms of the institutional architecture that regulates the functioning of public safety in Brazil, understood as the construction of links between the adoption of incremental modernization measures of the management of police forces activity and the defense of more substantive legislative changes.

\section{Keywords}

Public safety; Brazil; structural reforms; police forces; violence. 


\section{INTRODUÇÃO}

A democratização política do fim dos anos 1980 é um marco importante pelas mudanças na relação entre polícias e sociedade, suscitadas pela construção da democracia e pelas pressões sociais por novos modelos de política e de polícia; contudo, igualmente importante pelas continuidades de práticas, saberes e teorias que levam a constatar, em muitos elementos, que o Estado democrático limita-se a reproduzir relações que serviam ao governo ditatorial. Segurança pública, desse modo, acaba subsumida às forças policiais e, mesmo após a Constituição de 1988, não consegue ser pensada para além da gestão da atividade policial e da lógica do direito penal.

O fato é que a história recente da segurança pública no Brasil tem sido marcada por demandas acumuladas e mudanças incompletas. Ganhos, como a forte redução entre 2000 e 2014 dos homicídios em São Paulo, tendem a perder força, na medida em que não há normas técnicas, regras de conduta ou padrões capazes de modificar culturas organizacionais ainda baseadas na defesa do Estado e não da sociedade. Basta vermos a forma como as polícias reagiram às manifestações sociais de julho de 2013, ora com excesso, ora com omissão. Falta-nos um projeto de governança das polícias brasileiras e de alinhamento das políticas de segurança pública aos requisitos da democracia e à garantia de direitos humanos.

As instituições policiais e de justiça criminal não experimentaram reformas significativas nas suas estruturas. Avanços eventuais na gestão policial e reformas na legislação penal têm se revelado insuficientes para reduzir a incidência da violência urbana, numa forte evidência da falta de coordenação e controle. Num exemplo, temos um Congresso que há quase 27 anos tem dificuldades para fazer avançar uma agenda de reformas imposta pela Constituição de 1988, que até hoje possui diversos artigos sem a devida regulação, abrindo margem para enormes zonas de sombra e insegurança jurídica.

Para a segurança pública, o efeito dessa postura pode ser constatado na não regulamentação do artigo 23 da Constituição Federal, que trata das atribuições concorrentes entre os entes da Federação, ou dos parágrafos $7^{\circ}$ e $8^{\circ}$ do artigo 144, que dispõe sobre os mandatos e as atribuições das instituições encarregadas de prover segurança pública. A ausência de regras que regulamentem as funções e o relacionamento das polícias federais e estaduais, e mesmo das polícias civis e militares, produz no Brasil um quadro de diversos ordenamentos para a solução de problemas similares de segurança e violência sem, contudo, conseguirmos grandes avanços em boa parte do território nacional.

Este artigo pretende iniciar uma discussão sobre a necessidade de reformas estruturais no modelo de segurança pública e justiça criminal brasileiro, cujas respostas aos fenômenos do crime e da violência nos últimos 27 anos têm se mostrado insuficientes para a promoção de uma sociedade segura e garantidora de direitos.

Na primeira parte do artigo, traçamos um estado da arte brasileiro com a apresentação de estatísticas criminais, dados sobre o financiamento da segurança pública e o efetivo policial, associando-o às estratégias incrementais de integração e gestão experimentadas pelas 
unidades da federação entre a década de 1980 e os dias de hoje. Na segunda parte, analisamos como o conceito de segurança, tratado nas perspectivas "interna", "nacional" e "pública", foi recepcionado pelas Constituições Federais, e de que modo essas diferentes nomenclaturas influenciaram no desenho das políticas de segurança implementadas em cada período, revelando diferentes paradigmas e perspectivas acerca de como devem se organizar e atuar as instituições do campo.

Na sequência, apresentamos uma reflexão sobre a profissionalização do trabalho policial à luz das pressões por democratização e accountability inauguradas pela Constituição Federal de 1988.

Por fim, propomos a efetivação de uma agenda de reformas estruturais nos sistemas de segurança pública e justiça criminal brasileiros, modernizando as instituições do campo, mas sem perder de vista a necessidade de pensar ações incrementais que, no curto prazo, podem aumentar a eficiência das instituições da área.

\section{UM PANORAMA DA CRIMINALIDADE E DAS POLÍTICAS PÚBLICAS DE SEGURANÇA ${ }^{1}$}

A violência urbana persiste como um dos mais graves problemas sociais no Brasil, totalizando mais de 1 milhão de vítimas fatais nos últimos 24 anos. A taxa de mortes por agressão saltou de 22,2 no ano de 1990 para 28,3 por 100 mil habitantes em 2013, com variações importantes entre diferentes estados (Gráfico 1, p. 68). Estudo recente divulgado pelo Escritório das Nações Unidas sobre Drogas e Crime (UNODC) mostrou que o Brasil possui $2,8 \%$ da população mundial, mas acumula $11 \%$ dos homicídios de todo o mundo (UNODC, 2014). Como agravante, pesquisa produzida por Daniel Cerqueira, do Instituto de Pesquisa Econômica Aplicada (Ipea), calculou que, de 1996 a 2010, quase 130 mil homicídios no Brasil não entraram nas estatísticas de mortes violentas (CERQUEIRA, 2013). Isso significa que o número real de assassinatos no país é de cerca de 60 mil ocorrências anuais. Ou seja, se é verdade que o Brasil tem melhorado seus indicadores econômicos e sociais, o quadro de violência do país indica a convivência com taxas de crimes letais em muito superiores às de outros países e nos coloca no triste ranking das sociedades mais violentas do mundo, isso sem contar as altas taxas endêmicas de outros crimes violentos (roubos, sequestros, lesões, mortes pela polícia, etc.).

No que diz respeito à evolução regional, a Tabela 1 (p. 69) indica que São Paulo, por exemplo, que chegou a registrar mais de 12 mil vítimas de homicídio no ano de 1999, logrou redução de 68,2\% na taxa desse crime entre 2000 e 2013; já estados como Alagoas e Ceará verificaram crescimento abrupto dos índices de crimes violentos letais, alcançando taxas de

1 Laís Figueiredo e Patrícia Nogueira Pröglhöf contribuíram para a compilação dos dados contidos nesta seção. 
mortes por agressão de 65,5 e 50,9, respectivamente, em 2013.

Como agravante, pesquisas conduzidas no mundo, com destaque para aquelas que contam com a participação dos institutos Sou da Paz (SOU DA PAZ, 2013), de São Paulo, e Igarapé, do Rio de Janeiro (IGARAPÉ, 2013), demonstram que a maioria das mortes por agressão no Brasil ocorre por meio da utilização de armas de fogo. Armas essas que também impõem enormes desafios às políticas públicas da área e reforçam a agenda de supervisão, transparência e controle do Estado.

Afinal, por um lado e de acordo com a CPI do Tráfico de Armas, 85\% das armas apreendidas pelas polícias são brasileiras (CÂMARA DOS DEPUTADOS, 2006). Por outro, um contingente de armas com alto poder de impacto e destruição é provido pelo tráfico internacional e passa por portos e fronteiras mal monitoradas. Essas armas acabam nas mãos dos "soldados" do crime organizado e mudam o cenário das principais metrópoles brasileiras.

Por falar em crime organizado, esse é um problema que não pode ser desconsiderado na construção de um novo modelo de segurança pública para o Brasil. São vários os relatos de situações de violência extrema cometidas por grupos e facções criminosas no país, mas, ao mesmo tempo, muitos estudos têm demonstrado que o crime também tem parcela de responsabilidade por "pacificar” as periferias das cidades, em especial quando tais grupos buscam mitigar o impacto da ação das polícias.

Não à toa, com apoio do Banco de Desenvolvimento da América Latina (CAF), a Fundação Getulio Vargas (EAESP), a PUC Rio de Janeiro e o Fórum Brasileiro de Segurança Pública estão conduzindo um estudo longitudinal para avaliar a contribuição do Primeiro Comando da Capital (PCC) na redução dos homicídios em São Paulo entre 2000 e 2012. A hipótese do estudo é que a lógica monopolista imposta pelo PCC ao comércio e à distribuição de drogas na cidade de São Paulo trouxe, como efeito associado e tributário da atuação do grupo no interior das prisões, a necessidade de se controlar conflitos e crimes como tática de se maximizar lucros e ganhos - um homicídio por violência doméstica perto de um ponto de drogas, por exemplo, poderia trazer policiais e autoridades para a área e, se isso ocorresse, haveria risco de perda do controle territorial, base da atuação do crime organizado (BIDERMAN et al., no prelo).

Relacionada a esse quadro, a corrupção policial, por sua vez, é um tema que também chama atenção, mas pela falta de estudos e pesquisas mais recentes. Pouco se tem analisado sobre novas formas de atuação ilegal de agentes públicos. Do estudo clássico de Mingardi (1992) sobre a polícia civil, produzido nos anos 1980, pouco se aprofundou acerca do papel das instituições públicas encarregadas de enfrentar e prevenir a corrupção. Em especial, há uma agenda em aberto hoje no país sobre corregedorias e mecanismos de controle.

Somado a essa realidade, outro dado é revelador do quadro vivido pelo país na área e diz respeito às altas taxas de letalidade da ação policial no país. As polícias brasileiras atuam a partir de um padrão de policiamento que comporta um número de mortes em confronto muito superior aos observados em vários países desenvolvidos do mundo (Gráfico 2, p. 71). 
De acordo com Loche (2010), existem três critérios usualmente utilizados para aferir o uso da força letal: (1) a relação entre civis mortos e policiais mortos; (2) a razão entre civis feridos e civis mortos pela polícia; (3) a proporção de civis mortos pelas polícias em relação ao total de homicídios dolosos. Se o total de pessoas mortas pela polícia é muito superior ao de policiais mortos em serviço, se a ação da polícia produz mais mortes do que feridos, e se as mortes cometidas pela polícia correspondem a um elevado percentual do total de homicídios, pode-se inferir que a polícia está cometendo excessos no uso da força letal.

Segundo a autora, estudos realizados nos EUA demonstram que as mortes de civis decorrentes da ação policial representam 3,6\% do total de homicídios dolosos registrados em todo o país no período de cinco anos. No Brasil é difícil fazer o mesmo cálculo, pois os dados relativos a esse fenômeno são frágeis, mas, comparativamente, o percentual de mortos pelas polícias apenas em serviço em relação ao total de homicídios no ano de 2014 pelas polícias de São Paulo e Rio de Janeiro foi, respectivamente, 15,6\% e 11,8\%, mais de quatro vezes superiores ao índice americano.

Não à toa, diversos são os relatórios produzidos por entidades internacionais defensoras dos direitos humanos sobre violência policial no Brasil (ANISTIA INTERNACIONAL, 2005, 2007 e 2010; HUMAN RIGHTS WATCH, 1997 e 2009; ONU, 2007 e 2010).

Já no campo das respostas institucionais, é interessante aproveitar que a Lei de Responsabilidade Fiscal (Lei Complementar n. 101, de 4 maio 2000) obriga todos os entes da Federação a divulgarem seus gastos por funções e subfunções e analisar dados sobre despesas com segurança pública.

Assim, segundo os balanços contábeis da União, dos estados, do Distrito Federal e dos municípios brasileiros, sistematizados pela Secretaria do Tesouro Nacional, o Brasil gastou, em 2014, mais de R $\$ 70$ bilhões com segurança pública, aproximadamente 1,3\% do PIB nacional.

Em termos comparativos, temos o mesmo patamar de despesas na área que países como Alemanha e Espanha, que contabilizam taxas de homicídio inferiores a 1 por 100 mil habitantes, na evidência empírica de que o aumento de recursos na área não leva necessariamente a políticas de segurança mais eficientes no combate ao crime. Os gastos públicos nessa área parecem não guardar relação com a realidade, mas tão somente com as prioridades políticas assumidas pelas três esferas do Poder Executivo.

$\mathrm{Na}$ análise das despesas da União, estados, Distrito Federal e municípios chama a atenção: (1) o aumento nominal de recursos destinados à segurança pública realizado pelas UFs ano a ano não foi suficiente para manter a participação dessas unidades no total de recursos gastos pelas três esferas do Poder Executivo; (2) não obstante o incremento de 76\% nas despesas da União no período de 2002 a 2014, verifica-se perda de sua participação no último ano disponível da série; (3) o aumento expressivo de recursos na função "segurança pública" declarado pelos municípios que, nesse mesmo período, sofreu um incremento de 197\% (Tabela 2, p. 72). 
Os dados do gráfico 3 demonstram que, do total de despesas declaradas com segurança pública, os municípios saltaram de um patamar a 2,9\% dos gastos públicos na área, em 2002, para 5,5\%, em 2014. Os entes subnacionais assumiram um papel mais ativo (antes eles já financiavam gastos operacionais das polícias, como aluguéis, contas de consumo e manutenção e combustíveis das viaturas), porém esbarraram numa séria crise de financiamento de suas ações na área. Não há fontes de receitas específicas e há uma forte competição pelos repasses voluntários da União, que, a partir de 2001, com o Fundo Nacional de Segurança Pública, incluiu os municípios no rol de habilitados a receber recursos para essa área.

A União, por sua vez, aumentou sensivelmente seus gastos até 2010, com pequena redução nos últimos anos. Já as unidades da federação (estados e Distrito Federal) permanecem como as responsáveis por cerca de $83 \%$ do total de gastos públicos com segurança pública, em muito justificados pelas folhas de pagamento dos aproximadamente 542 mil policiais civis e militares do país.

Analisando as despesas declaradas com segurança pública entre 2002 e 2014, cujos valores foram corrigidos pelo IPCA a preços de dezembro de 2014, verificamos que os municípios são, em boa parte, responsáveis pelo incremento dos gastos na área. Isso porque a União apresentou um crescimento de 76,8\% entre 2002 e 2014, média de 6,4\% por ano; as unidades da federação apresentaram um incremento de 50,8\% no período, média anual de 4,2\%, enquanto os municípios apresentaram crescimento de 197,6\%, média anual de $16,4 \%$.

Seja como for, o país gasta o equivalente a países desenvolvidos e nem por isso consegue reverter o quadro de medo e insegurança, muito em função de um modelo falido de organização policial e administração de conflitos. Como dito na introdução, é possível supor que o crescimento dos gastos com segurança pública é um efeito inevitável de se optar por manter um sistema disfuncional na prevenção da violência e na garantia de direitos e que, para continuar de pé, exige volumes crescentes de investimentos. Todavia, essa opção não se dá pelo sucesso desse sistema em fazer cumprir o monopólio estatal da violência e oferecer serviços de qualidade. Ao contrário, ela parece guardar mais relação com os sentidos e prioridades políticas que o tema assume para os dirigentes políticos (Gráfico 3, p. 73).

Em termos de efetivo policial, as fontes existentes computam que o Brasil tenha 425.248 policiais militares, 117.642 policiais civis e 99.354 guardas municipais, totalizando 642.244 homens e mulheres (Tabela 3, p. 74).

Já sobre o sistema prisional brasileiro, convivemos ainda com um sistema de justiça que não é capaz de julgar os 222.190 encarcerados em situação provisória nas prisões brasileiras, mesmo frente a um déficit de 203.531 vagas, segundo dados do Anuário Brasileiro de Segurança Pública para o ano de 2014.

A realidade de oito estados é ainda mais grave na medida em que verificamos que mais de 50\% da população prisional não foi julgada: Sergipe com 70,9\%; Piauí com 63,6\%; Pernambuco com 59,1\%; Amazonas com 56,6\%; Bahia com 54,9\%; Maranhão com 54,8\%; 
Mato Grosso com 52,8\%; Roraima com 50,3\% (Tabela 4, p. 75).

Além da evidente incapacidade do sistema de justiça criminal brasileiro de processar e julgar a população carcerária que se amontoa nos presídios de todo o país, chama atenção a evolução do número de presos com relação às vagas existentes no sistema prisional: só o estado de São Paulo contabiliza um déficit de 84.394 vagas no ano de 2014. Para se ter uma ideia, cada penitenciária do estado possui cerca de 800 vagas, ou seja, seria necessária a criação de 105 penitenciárias para dar conta desse passivo (Tabela 5, p. 76).

\section{I INTEGRAÇÃO E GESTÃo}

Numa aparente contradição, apesar do contorno dramático que o campo da segurança tem assumido no Brasil nos últimos anos, não podemos deixar de reconhecer avanços significativos em determinados territórios que, se não foram capazes de provocar mudanças efetivas no modelo de segurança pública, representaram ganhos incrementais e pautaram discussões mais qualificadas sobre o tema na agenda das políticas públicas. Representaram a inclusão de novos temas e atores no debate sobre segurança pública no Brasil, com destaque para a universidade e para a sociedade civil.

Dito de outra forma, o colapso do sistema de justiça e segurança pública descrito anteriormente tem merecido a atenção de diferentes atores políticos e sociais, mas, paradoxalmente, essa mesma atenção não tem sido suficiente para ir além de medidas incrementais; não tem sido suficiente para inserir o tema das reformas estruturais da segurança pública no rol das prioridades da agenda pública nos últimos 27 anos.

Nessa direção, a linha do tempo a seguir inventaria algumas das principais ações da União, das unidades da federação e dos municípios no campo da segurança pública, desde a década de 1980, na ideia de identificar pontos de convergência e propostas mais eficientes para o aprimoramento do sistema de justiça e segurança pública.

Afinal, a história recente das políticas de segurança nos ensina que, entre as ações que mais tiveram êxito em conter as taxas de violência, o envolvimento com a comunidade tem sido mais eficiente se associado a práticas integradas de gestão, pelas quais há uma irredutível aliança entre técnica e política. E nessa aliança, as melhores práticas concentraram suas energias no tripé aproximação com a população, uso intensivo de informações e aperfeiçoamento da inteligência.

No entanto, por melhores que sejam essas práticas de gestão, sem uma mudança substantiva na estrutura normativa das polícias e do sistema de justiça criminal, o quadro de insegurança hoje existente tenderá a ganhar contornos dramáticos. Uma das lições de países que conseguiram reformar suas polícias, como Irlanda e África do Sul, é que quando a atividade policial deixa de ser autônoma e passa a responder à lógica das políticas públicas muito se ganha. Para além de soluções puramente técnicas, percebe-se que os problemas da área podem ser mitigados quando a política está efetivamente comprometida na construção de uma nova postura do Estado em relação à sociedade (Quadro 1, p. 78). 


\section{Constituições Federais e contexto político-institucional}

Diante do panorama descrito, nota-se que o modelo de segurança pública brasileiro guarda pouca relação com as demandas sociais e políticas contemporâneas e não está preparado para fazer frente às novas dinâmicas do crime, que muitas vezes envolve organizações criminosas, corrupção e violência. Mas por que é tão difícil avançar numa agenda de reformas substantivas das instituições?

Para responder a essa pergunta e, como propugnou Costa (2014), para compreender as dinâmicas próprias das organizações responsáveis pela segurança pública no Brasil, é necessário apreender como determinadas práticas são institucionalizadas, como as identidades são formadas, como novos conceitos e atores são incorporados e como os conflitos estão estruturados. No caso da segurança pública, um olhar sobre como ela foi recepcionada pelas Constituições brasileiras e pela legislação demonstra, uma vez mais, que estamos diante de um conceito "em aberto".

O termo segurança "pública" parece ter sido usado pela primeira vez na Constituição Federal (CF) de 1937. Em outras Constituições, como a de 1934, aparece o termo segurança "interna" para tratar com matérias atinentes ao controle da ordem, fato que irá gerar vários dilemas organizacionais no país e em seu pacto federativo. É interessante constatar que, na CF de 1937, cabia exclusivamente à União a competência de regular a matéria e garantir "o bem-estar, a ordem, a tranquilidade e a segurança públicas, quando o exigir a necessidade de uma regulamentação uniforme" (artigo 16, inciso V).

Nota-se aqui uma primeira tensão conceitual e que terá impacto direto nos mandatos e atribuições das polícias brasileiras. A Lei n. 192, de 17 de janeiro de 1936 (anterior à CF de 1937, portanto), regulava as atividades das polícias militares e as vinculava às unidades da federação, cabendo à União apenas um papel de supervisão e controle, por meio do Exército.

Por essa lei, as polícias militares eram as responsáveis pela segurança "interna”, enquanto a CF de 1937 fala de segurança "pública", atividade que formalmente não foi assumida por nenhuma instituição até a CF de 1988. O significativo é que essa lei só foi revogada pelo Decreto-Lei n. 317, de 13 de março de 1967, que regulamentou a CF de 1967 no que tange à atuação das polícias. O conceito criado pela CF de 1937 parece não ter conseguido se institucionalizar e não teve força para mudar, mesmo após o Estado Novo, as estruturas que organizavam as polícias estaduais. E ainda mais emblemático dessa dificuldade é que a CF de 1967 reestabeleceu a competência das polícias militares para a "manutenção da ordem e segurança interna nos Estados, nos Territórios e no Distrito Federal” (grifo nosso).

Será somente a CF de 1988 que irá resgatar o conceito de 1937 e trará um capítulo específico sobre segurança "pública", não obstante repetir a CF de 1937 e não definir o significado desse conceito. A CF de 1988, em seu artigo 144, definirá tão somente quais são as instituições públicas encarregadas de prover segurança "pública” (LIMA, 2011). Em suma, nossa atual Constituição não define o que vem a ser segurança pública, apenas delimita quais organizações pertencem a esse campo. 
Todavia, os ruídos no pacto federativo e no modelo bipartido de organização policial (civil e militar), herdados de períodos anteriores, não foram enfrentados pela CF de 1988 e, ao contrário, novas situações de fricção foram criadas com a introdução dos municípios na formulação e execução de políticas de prevenção e combate à violência. Segundo Lima (2011), a CF de 1988 avançou na construção de um novo conceito de segurança "pública", mas, ao que tudo indica, apenas em oposição ao de segurança "nacional", na tentativa instrumental de fornecer ao Estado condições e requisitos democráticos de acesso à justiça e garantia de direitos.

Entretanto, pela análise das Constituições Federais, percebe-se que as polícias estaduais estavam menos orientadas pela "agenda" da segurança "nacional" e pautavam - e por vezes ainda pautam - suas culturas organizacionais pela lógica da segurança "interna", de forte influência no meio policial.

Numa revisão historiográfica, constata-se que a doutrina da segurança "nacional" havia sido reivindicada pelas forças armadas desde a Revolução Constitucionalista de 1930, apartando-a das polícias. A própria Lei n. 192 é fruto desse fato, ao impor uma série de restrições e controles às polícias militares, como as que as proibiam de adquirir ou manter peças de artilharia e, com isso, limitar o poder dos estados e fortalecer a União. As polícias foram instrumentalizadas, mas não absorvidas por essa doutrina, cabendo a essas organizações um papel muito mais de controle da ordem interna.

A conclusão possível é que o conceito de segurança “interna”, reestabelecido pela CF de 1967 e regulamentado pelo Decreto-Lei n. 317, de 13 de março de 1967, será, mesmo após 1988, central para a formação da agenda das políticas de segurança "pública" no país. Na inexistência de contrapontos, ele vai sendo reinterpretado e mantido como o modus operandi das organizações da área. O problema é que ele foi e é estruturado em torno da ideia de defesa dos interesses do Estado.

Assim, os enunciados legitimados continuam a ser os provenientes dos universos jurídico-penal e do combate ao inimigo. No primeiro caso, trata-se apenas da redução de conflitos sociais a tipos penais, desprezando a natureza dos conflitos e suas configurações, que engendram regras e padrões de sociabilidades, constituem e põem em confronto identidades individuais e coletivas. No segundo caso, segmentos sociais são vistos como intrinsecamente perigosos e objeto constante de vigilância e neutralização. A visão penalizante e técnica deslegitima, em decorrência, a participação social e a contribuição de outros profissionais e saberes para a administração de conflitos.

A CF de 1988 avançou na sinalização de um novo conceito de segurança pública. Algumas inovações para o cotidiano do trabalho policial merecem destaque: a abolição da prisão correcional e a completa judicialização de todas as modalidades de prisão, retirando da discricionariedade policial a prisão administrativa. Isso foi uma mudança simbólica de importância, que levou contingentes de policiais a criticar a normatividade democrática por ter ela "retirado os instrumentos de trabalho da polícia". Porém, nunca é demais ponderar que 
as pesquisas recentes têm demonstrado que a tendência majoritária dos juízes é de conceder os pedidos de prisão provisória dos delegados (VASCONCELLOS, 2008).

No entanto, as inovações não conseguiram força para alterar a arquitetura institucional, e a teoria prevalecente continuou a operar a partir dos enunciados acima destacados, pouco alterando a estrutura normativa e burocrática de administração dos conflitos. As mudanças sempre se deparariam com o risco da descontinuidade, na medida em que estavam lastreadas apenas na vontade política e não lograram mudar a "lógica em uso" das instituições policiais, para usar o termo acionado por Antonio Luiz Paixão, um dos primeiros cientistas sociais brasileiros a se aproximar do tema e dos próprios policiais, ainda na década de 1970 .

Nessa medida, durante os anos 1990, o tom geral das reformas legislativas mantevese no "combate ao crime", diante de uma percepção social generalizada de que a violência vinha extrapolando todos os limites. Desde o homicídio à defesa de direitos coletivos e difusos, as reformas legislativas lançaram mão do endurecimento penal como principal estratégia de controle social do crime (AZEVEDO, 2003). Por todos os lados, os grupos sociais mais diversos lançaram-se no debate sobre o crescimento da violência, movidos pela ocorrência de uma desanimadora coleção de casos graves e de grande repercussão (Massacre do Carandiru, rebeliões na Febem de São Paulo, chacinas da Candelária, de Vigário Geral e de Eldorado dos Carajás, entre outros), tendo por pano de fundo uma escalada das taxas de homicídio e de outros crimes violentos. A emergência e a politização do tema do combate à violência durante os primeiros anos da democracia tiveram o efeito de frear as pretensões de reforma do sistema de justiça e, em vez da reforma, pautaram o reforço das estruturas já existentes: mais polícia, mais prisão, mais pena (para adultos e para adolescentes), mais armamento.

Com muito custo, os críticos dessas escolhas procuravam manter-se fiéis ao espírito da redemocratização e da necessidade de reformas. A conjuntura do descontrole da violência desfavoreceu o debate sobre reformas institucionais, valorizando as ações emergenciais, mas foi ela também que, persistindo, forçou a necessidade de debate público sobre segurança, justiça e polícia. Por isso é que, se no plano normativo continuou-se a insistir em mais do mesmo, não se pode dizer que as relações entre polícia, Estado e sociedade tenham permanecido as mesmas do início dos anos 1980. Há um deslocamento de foco das polícias em direção à política de segurança pública, na qual novos atores entram na disputa.

Certamente muitos fatores contribuíram para as mudanças, e a compreensão desses fatores requer atenção a múltiplos níveis de análise, que envolvem questões internas à corporação policial e sua luta por melhores condições de trabalho, bem como transformações nas percepções sociais da violência, aumento da competição profissional para a definição do campo da segurança pública, aumento da pressão das organizações da sociedade civil para participação na formulação das políticas, consolidação de uma percepção social de ineficiência da polícia diante do crescimento e das transformações do crime. Todos esses fatores, 
e mais alguns outros, pressionam a polícia por mudanças, apesar da aparente manutenção do status quo ante.

Num paradoxo com a lógica do endurecimento penal, outra inovação significativa veio da pena de civilistas e processualistas, com a Lei n. 9.099/99 que criou os Juizados Especiais cíveis e criminais. Na onda das reformas informalizantes da justiça, em muito justificadas pela busca de celeridade e eficácia, os juizados eliminaram um conjunto de procedimentos burocráticos constitutivos do inquérito policial para os crimes de menor potencial ofensivo, reduzindo com isso parcela significativa da intervenção policial na administração dos conflitos. Uma parte dos policiais considerou isso uma melhoria das suas condições de trabalho, por diminuir o volume das tarefas acumuladas nos plantões policiais; outra parte viu na implantação dos juizados uma usurpação do poder da polícia, vendo escapar de suas mãos a administração desses conflitos. De um lado, os juizados foram recebidos com entusiasmo por serem uma alternativa despenalizante para a administração de conflitos; de outro, foram criticados por propiciar impunidade, principalmente dos crimes ocorridos em relações interpessoais e, especialmente, quando envolvem relações conjugais. De um jeito ou de outro, a criação dos juizados provocou perturbações nos papéis profissionais clássicos de todos os operadores do sistema de justiça e segurança.

\section{Pressões internas, disputas profissionais e corporativas num campo EM CONFLITO}

A análise sobre Judiciário e Ministério Público no Brasil tem enfatizado muito as transformações nos papéis dessas instituições na ordem democrática. Elas teriam incorporado a administração de conflitos coletivos e com isso se tornado muito mais politizadas e abertas a inovações legislativas e processuais (SINHORETTO, 2007). Nos estudos que abordam a politização da justiça, a polícia tem pouco destaque, como se tivesse ficado alheia a essa politização, aparecendo apenas por ocasião de inquéritos envolvendo políticos e administradores públicos, e, mesmo nesses casos, exercendo funções clássicas de polícia, como investigação, levantamento de provas e cumprimento de prisões.

Contudo, o que se pode ver do ponto de vista das relações internas das corporações policiais é que elas também conheceram um grande movimento de politização, não exatamente nos mesmos termos do que vem acontecendo no Judiciário, mas com a introdução de temas de reforma, novos conteúdos e novas práticas e discursos. São exemplo as reformas gerenciais iniciadas no final dos anos 1990, início dos anos 2000, as quais introduziram no debate sobre polícia a necessidade de padronização da formação profissional e o uso intensivo de ferramentas de gestão, tecnologia e planejamento.

Assim como o aumento da politização do Judiciário não alterou estruturalmente os modos como a instituição administra conflitos, nas polícias, de certa forma, continua-se fazendo o que se fazia antes, seja numa vara criminal, num distrito policial ou numa viatura; mudou, 
porém, o enquadramento mais geral em que as práticas clássicas estão hoje inseridas. Velhas formas de resolver conflitos e administrar crimes persistem, todavia elas não estão mais sozinhas no cenário e veem seu espaço ser disputado por novos discursos e novos modos de fazer, certamente minoritários, mas indeléveis. Diferentemente do que ocorreu com Judiciário e Ministério Público, as mudanças no cotidiano policial não são decorrentes de mudanças legislativas, da introdução de novos tipos criminais ou de reformas processuais; são decorrentes de tensões introduzidas pelo tema da gestão policial e da necessidade de gerir melhor as políticas públicas de segurança.

Diante do conhecimento já acumulado sobre o funcionamento das polícias brasileiras, obtido por meio de estudos de caráter etnográfico (KANT DE LIMA, 1995; MINGARDI, 1992; PAIXÃO, 1982), não se pode ignorar que, para além das estruturas formais definidas pela lei, pelos planos e políticas públicas para o trabalho policial, há organizações informais que operam as polícias por meio de redes profissionais de informações e saberes. E a existência dessa dimensão informal - que no caso de qualquer polícia é poderosa, especialmente no caso brasileiro - faz com que qualquer plano de reforma da segurança que não leve em conta como efetivamente se dá o trabalho policial, esteja fadado a não ser mais do que uma boa intenção a disputar espaço com o que já está consolidado. Faz-se necessário que os isomorfismos que moldam as instituições entrem na equação para que reformas efetivamente aconteçam - esse é um ponto particularmente importante no debate acerca da desmilitarização das polícias militares.

A polícia tem poder discricionário e isso em si é um importante contraponto à estruturação burocrática de cargos e funções. Por mais piramidal que seja a estrutura de comando da polícia, as decisões mais importantes relativas aos direitos civis são tomadas por agentes da base, o que faz a polícia ter de fato uma grande autonomia em relação aos planos dos governos civis e aos controles formais da lei e da própria instituição (PAIXÃ O, 1982). Antagonismos e conflitos no cotidiano profissional opõem, nesse caso, redes de relação e prestígio que têm diferentes visões sobre a estrutura formal da polícia e sobre as políticas governamentais.

Algumas redes se apropriam de modos particulares de administração de conflitos, que podem envolver relações políticas, relações com redes criminosas, mercantilização das funções públicas, administração extralegal de conflitos (que vai da facilitação da negociação de interesses entre as partes até a execução sumária de criminosos). Algumas redes de policiais exercem funções que claramente contrariam a lei, porém a questão é imensamente mais complexa, uma vez que as redes, por meios informais, operam o cotidiano do trabalho policial, hierarquizando postos de trabalho, funções, tipos de tarefas, os policiais adequados a cumpri-las, os destinatários do trabalho policial. Prestígio e escassez são operados pelas redes profissionais, que possuem seus saberes e práticas e têm função primordial de fazer circular - ou bloquear a circulação - dos conhecimentos necessários para o trabalho cotidiano. Portanto, é praticamente impossível estar na polícia fora do 
contato com as redes profissionais; até mesmo os defensores de reformas e mudanças de paradigma constituem suas redes no interior das polícias.

Isso significa que a política no interior da polícia, para usar termos de Mingardi (1992), pode neutralizar propostas de mudança vindas “de fora”, mas é exatamente o mecanismo de disputas entre redes de prestígio que, a longo prazo, permite pensar em mudanças. Quando a primeira Delegacia de Defesa da Mulher foi criada em São Paulo, em meados dos anos 1980, nada assegurava que ela poderia introduzir uma ruptura na lógica de atendimento das vítimas de violência. Mas o projeto foi incorporado por certos policiais, criando uma nova identidade profissional, e apoiado pelos movimentos feministas, de maneira que as experiências de Delegacia da Mulher se espalharam pelo país todo, a ponto de ser uma das especializações policiais mais consolidadas, atraindo vocações, saberes, interesses e recursos. Hoje, redes policiais estão articuladas aos movimentos sociais e a redes políticas, de maneira que já não se pode voltar atrás no espaço conquistado. É claro que do ponto de vista do perfil policial majoritário, as Delegacias da Mulher e os seus profissionais continuam ocupando uma posição bastante minoritária na definição do campo policial, mas, desde essa posição minoritária, politizam as práticas policiais, introduzem novos temas e saberes.

Falamos da importância de redes profissionais na recepção ou rejeição de projetos de mudança e na possibilidade de politizar o trabalho policial para a defesa de direitos civis através das próprias redes. Porém, seria mais adequado, no caso das polícias, falar em redes corporativas, uma vez que a profissionalização do trabalho policial, no sentido de autodefinição de um campo de saberes e práticas que delimitaria o que é o bom trabalho de polícia e o que são as práticas inaceitáveis e tidas como antiprofissionais, é muito incipiente no Brasil (COSTA, 2003). Entre as carreiras jurídicas, a profissão dos delegados é a mais incipiente, não do ponto de vista da reserva de mercado, mas da proteção da carreira contra influências políticas externas (BONELLI, 2002). As carreiras de agentes são ainda mais frágeis na medida em que não exigem diploma universitário para serem exercidas; dito de outro modo, agentes e investigadores de polícia não têm um saber reconhecido. Além disso, as pesquisas sobre especialização do conhecimento no trabalho policial indicam uma grande diferença entre os conteúdos ensinados nas academias e as necessidades do trabalho cotidiano. Não se trata apenas de uma defasagem entre teoria e prática, mas de um modo de organização institucional que não leva em conta a especialização do conhecimento, mas a filiação do membro às redes corporativas, pois elas definem a alocação nos postos de trabalho, as promoções e punições, a transmissão do saber policial (NASCIMENTO, 2009; PONCIONI, 2004).

Diante disso, uma das formas de incrementar a adesão de policiais a um modelo de policiamento democrático e cidadão é induzir, através de políticas de formação profissional, a formação de redes profissionais no sentido estrito, isto é, baseada no compartilhamento e na defesa de conhecimentos técnicos específicos e de critérios internos de validade e legitimidade 
que definam o que não é aceitável na prática policial. Algumas ações desenvolvidas recentemente apontam nessa direção, mas ainda é cedo para que o seu impacto possa ser avaliado diante desse amplo objetivo. É o caso do investimento em formação profissional, da constituição pelo Ministério da Justiça de uma rede de capacitação como a Rede de Altos Estudos em Segurança Pública (Renaesp), ou mesmo da criação do Fórum Brasileiro de Segurança Pública, em 2006, que visa fazer circular referências técnicas sobre policiamento democrático e constituir novos enunciados políticos para o campo.

Embora ainda pareça ser um tema pautado de "cima para baixo", cada vez mais as exigências salariais e de melhoria das condições de trabalho dos policiais vão esbarrar na acusação de ineficiência e falta de profissionalismo, fortalecendo as demandas por mudanças. Tanto o Estado quanto a sociedade civil têm resistido em reconhecer a autonomia profissional da polícia por considerarem seu trabalho excessivamente arbitrário e muito pouco autorregulado, além de cobrarem eficiência, a qual só poderá ser medida por critérios consensuados e transparentes.

A questão da profissionalização é um dos temas em que as pressões por democratização e accountability vão se associar a interesses corporativos, mas as mudanças só avançarão no sentido da democratização se grupos profissionais dentro das polícias incorporarem essas agendas, por acreditarem que ganharão com isso prestígio social e melhores condições de trabalho. O caso do Ministério Público é indicativo de que uma carreira pode incrementar seu prestígio social através de uma reorientação política de seus objetivos e de suas parcerias com a sociedade civil organizada; a instituição, antes restrita à atuação penal, lançouse na defesa de direitos coletivos e teve participação ativa na ampliação do conceito de cidadania no sistema jurídico brasileiro - mesmo que, na prática, a instituição que assumiu o discurso político da transparência seja uma das mais opacas do sistema de justiça brasileiro. Um grande número de policiais reivindica equiparação salarial e de vantagens e garantias funcionais aos promotores - resta saber se eles estariam dispostos a assumir compromissos políticos semelhantes aos assumidos pelos promotores à época da democratização política.

Os problemas de profissionalização e reconhecimento público de eficiência envolvem ainda uma questão muito mais complexa do que a formação e a defesa de um campo autônomo de atuação. A polícia ocupa um lugar muito específico no campo da administração de conflitos, e esse lugar coloca as instituições e seus agentes em posição liminar e passível de acusação sistemática de erro e abuso. Isso porque o campo de administração de conflitos no Brasil é disputado por lógicas jurídicas contraditórias entre si; uma oficial, formal, inscrita nas regras constitucionais, orientada pela igualdade jurídica de todos os cidadãos diante das leis; outra, informal, orientada por uma lógica jurídica não escrita, que administra os conflitos levando em conta as posições hierárquicas das partes conflitantes. Sendo assim, qualquer agente policial, em qualquer posição, decide se implementa uma solução informal ou se aplica procedimentos previstos em lei; porém, em qualquer das decisões, pode ser cobrado por seus superiores ou pela opinião pública em função de outra lógica. Se fizer a 
prisão em flagrante de um homem que agrediu a cônjuge, pode ser acusado pela população de não saber diferenciar um pai de família de um bandido "verdadeiro". Se não faz a mesma prisão, pode ser acusado de conivência e de prevaricação pelo movimento feminista. Esse é apenas um exemplo hipotético que pretende ilustrar o eterno dilema que mantém o saber e a prática policial presos a uma posição passível de deslegitimação permanente (KANT DE LIMA, 2004).

Essa cultura jurídica particular, que combina regras jurídicas igualitárias a lógicas sociais hierarquizantes, impulsiona as instituições formais a permanentemente administrarem conflitos por vias informais. A informalidade serve a evitar o tratamento legal igualitário a litigantes desiguais, serve à adaptação das situações a conveniências pessoais e estatutárias dos agentes e pode até atender às expectativas das próprias partes, quando se satisfazem com as soluções que repõem a ordem hierárquica.

Assim, tão verdadeiro quanto dizer que há uma parte da sociedade brasileira que reivindica a proteção aos direitos civis e luta pela instituição de tratamento jurídico igualitário é dizer que há muitos interessados na solução de conflitos pela lógica hierarquizante (portanto, fora do sistema legal), e ainda que há outros tantos que procuram manipular essas ambiguidades para obter privilégios e defender interesses particulares.

De um lado, é necessário constatar que o campo estatal de administração de conflitos vem sendo tensionado por lutas políticas em diversas esferas, e atores politizados têm procurado introduzir inovações para lidar com a tensão. De outro, dada a fragmentação e a hierarquização do campo, muitas das políticas institucionais ou dos programas de melhoria de acesso à justiça terminam por constituir apenas mais um serviço e uma instância fragmentada, cujo prestígio em geral é muito pequeno. Os pesquisadores têm constatado que isso se passa com a justiça da infância e juventude (SILVA, 1996), as Delegacias de Defesa da Mulher (IZUMINO, 2002; e estudos reunidos em DEBERT; GREGORI; PISCITELLI, 2006), os juizados especiais (AZEVEDO, 2000) e os Centros de Integração da Cidadania (SINHORETTO, 2007); todas elas inovações pensadas para reformar o sistema de justiça e a administração de conflitos ao ressignificar categorias e formas de tratamento ou reconstituir o estatuto de sujeitos de direitos; todas elas inovações que parecem ter ficado aprisionadas a lógicas de poder e formas de administração de conflitos muito mais resistentes.

Nesse ponto, os problemas de ausência de padronização do trabalho policial e ausência de critérios e dados que permitam medir a eficiência desse trabalho não são mais apenas questões de baixa profissionalização ou de falhas na gestão organizacional; são dilemas que atravessam a sociedade brasileira de alto a baixo e que dizem respeito à dificuldade de implementar uma cultura jurídica igualitária numa sociedade multiplamente hierarquizada (DaMATTA, 1979). Essa mesma cultura jurídica da ambiguidade faz com que os indivíduos tenham dificuldade de introjeção das regras públicas, porque elas oscilam o tempo todo entre regimes jurídicos contraditórios, fazendo com que, em certos assuntos, a violação da lei seja mais frequente do que o seu cumprimento (MISSE, 1999). 
A polícia é o ponto mais visível em que se manifesta a contradição de uma sociedade que reluta em aprofundar a sua democracia, introduzindo barreiras à extensão de direitos civis a todos os grupos sociais. Por trás dessa constatação aparentemente óbvia, encontra-se uma das mais duras batalhas em torno de como administrar conflitos e, em decorrência, de como definir categorias que tornem possível pensar no enfrentamento da violência e de práticas criminosas a partir de novos enquadramentos e do ordenamento democrático inaugurado em 1988 .

Nesse sentido, a tentativa de apresentar aqui uma discussão sobre a questão da segurança pública teve o objetivo de ajudar-nos a identificar alguns dos elementos que tornam esse sistema impermeável às mudanças exigidas por uma sociedade democrática e, ato seguinte, políticas públicas que busquem neutralizá-los ou, ao menos, mitigá-los.

Por esse raciocínio, o significado fundamental dos dados e das discussões compilados neste texto é que traduzem, em primeiro lugar, uma enorme dificuldade da sociedade brasileira de se desvencilhar de suas históricas estruturas autoritárias e deixar que o cidadão usufrua de amplos direitos, com liberdade, participação e acesso a justiça, tal como previsto no nosso marco legal. Em segundo lugar, vencer o desafio político-institucional implica na aliança entre medidas incrementais com foco no ensino, na gestão e na modernização tecnológica do Estado; e a efetivação de uma agenda de reformas estruturais, que não sejam apenas de natureza legal.

Ou seja, sem uma pauta de reformas estruturais, que inclui mudanças legislativas e fomento às novas práticas organizacionais lastreadas em fortes elos com a transparência e a prestação de contas, sem o fortalecimento de mecanismos de controle ou ainda o incentivo à participação social, pouco conseguiremos avançar em termos de eficiência democrática das políticas de segurança. Nesse movimento, os novos atores da segurança pública, como as universidades, podem contribuir com aportes de competências e repertórios que rompam efetivamente com os isomorfismos hoje atuantes.

As tensões e os antagonismos que hoje se fazem presentes no campo da segurança pública podem e devem ser convertidos em janelas de oportunidade para a construção de consensos e paradigmas legais e organizacionais mais alinhados com os pressupostos democráticos; mais alinhados com a perspectiva da segurança pública como a prestação de um serviço para a sociedade e não como a imposição da vontade do Estado.

\section{A CONFOrmaÇÃo de UMA AgENda POLÍTICA DE MODERNIZAÇÃo DEMOCRÁTICA DE PRÁTICAS INSTITUCIONAIS}

A síntese dos dados apresentados neste texto indica que o país convive há anos com taxas de violência criminal absurdas, que naturalizam quase 60 mil homicídios por ano, mais de 50 mil estupros registrados e padrões operacionais inaceitáveis de letalidade e vitimização

policial, que fazem com que ao menos oito pessoas sejam mortas por dia pela intervenção das 
polícias e que o risco de um policial ser morto seja, em média, três vezes superior ao da população como um todo.

Isso para não falar nas constantes ameaças do crime organizado; no crescimento dos roubos; nos reiterados incêndios de ônibus nas periferias paulistanas; no aumento dos "sequestros-relâmpago" no Distrito Federal; ou nos novos justiceiros cariocas, que acorrentam acusados de crimes em postes. As polícias, os governos, os ministérios públicos e o Poder Judiciário, insulados em seus projetos de corporação e em suas práticas institucionais, não conseguem fazer frente aos desafios contemporâneos impostos pelo crime, pela violência e pela dinâmica de uma sociedade plural e democrática.

O fato é que nosso sistema de justiça e segurança é muito ineficiente em enfrentar tal realidade e funciona a partir de um paradoxo que mais induz a antagonismos do que favorece a indução de cooperação e a troca de experiências. Paradoxo esse que, por um lado, nos faz lidar cotidianamente com elevadas taxas de impunidade, erodindo a confiança nas leis e nas instituições, como têm demonstrado os vários índices do Centro de Pesquisas Jurídicas Aplicadas da FGV Direito SP.

Por outro lado, as instituições de segurança pública e justiça criminal, premidas pelas cobranças da mídia e da opinião pública, são regidas pela ideia de que algo precisa ser feito a qualquer custo para conter os "criminosos", abrindo margens para medidas de extremo rigor penal e, mesmo, para reforçar políticas criminais anacrônicas.

$\mathrm{Na}$ falta de parâmetros mais modernos sobre como lidar com crime, violência, manifestações e quaisquer ameaças à ordem social, recorre-se ao discurso de que o país tem leis lenientes e que é necessário endurecer o tratamento penal. Todavia, ao fazer isso, as instituições erram no diagnóstico e erram no remédio.

E, por essa perspectiva, na ausência de uma política de segurança pública pautada na articulação de energias e esforços para a garantia de direitos, no respeito e na não violência, deixamos de enfrentar o fato de que o nosso sistema de justiça e segurança necessita de reformas estruturais mais profundas. E não se trata de defendermos apenas mudanças legislativas tópicas ou, em sentido inverso, focarmos apenas na modernização gerencial das instituições encarregadas de prover segurança pública no Brasil.

Nosso desafio é adensar politicamente a defesa de que, exatamente, essas são duas faces complementares de um mesmo processo e que nenhuma delas conseguirá êxito permanente sem que a outra seja simultaneamente assumida também como prioridade. Temos que modernizar a arquitetura institucional que organiza as respostas públicas frente ao crime, à violência e à garantia de direitos. O foco, a nosso ver, não está no debate exclusivo da legislação penal e processual penal e/ou na gestão incremental da ordem conservadora, mas na forma como o Estado organiza e administra seus poderes e instituições.

Por esse raciocínio, por mais importantes que sejam as iniciativas recentes (UPPs, Polícia Comunitária, Uso Intensivo de Informações do tipo Infocrim, entre outros), elas possuem caráter incremental e não são suficientes para transformar o cenário político e institucional 
hoje vigente, dado que ainda há várias zonas de incerteza advindas da não regulamentação da Constituição Federal que, no limite, enfraquecem essas medidas na lógica do se nada mudar no plano legislativo, elas tendem a perder força e repetir os mesmos vícios do sistema de segurança como um todo.

Isso porque, ao contrário do que pensa o senso comum, muitas energias são gastas na busca por soluções e há várias iniciativas que podem e devem ser mais bem estudadas e incentivadas. As melhores práticas na redução da violência e da criminalidade têm se concentrado no tripé aproximação com a população, uso intensivo de informações e aperfeiçoamento da inteligência e da investigação.

A questão é que tais práticas, sozinhas, não conseguem dar conta de um elemento central que é a carência de coordenação, de integração e de articulação, marcas registradas da segurança pública brasileira e da arquitetura jurídica que embasa as políticas públicas no país. Sem que ataquemos essa grande fragilidade, o país continuará refém do medo e da insegurança e pouco conseguiremos avançar na transformação de práticas institucionais reconhecidamente ineficazes.

O maior exemplo de que é possível pensar segurança pública de modo diferente e mais eficaz foi, exatamente, o esforço feito para garantir a segurança durante a Copa do Mundo e que esteve baseado na proposta de compartilhamento de responsabilidades entre diferentes organizações e esferas de poder e governo. Compartilhamento esse que permitiu uma enorme reversão de expectativas que, por sua vez, previam o colapso da infraestrutura e da segurança pública e apostavam numa exitosa campanha da nossa seleção masculina. O fato é que a Copa foi encerrada sem grandes crises na segurança muito em função da centralidade política e institucional que ganhou durante sua realização. Governos e instituições sentaram-se no mesmo espaço e articularam suas ações e integraram planejamento e operações, pensando mais nos resultados e menos nas suas lógicas autônomas de funcionamento. E, como fruto dessa iniciativa, os índices de criminalidade mostraram-se sensíveis a essa mudança de comportamento e caíram em vários lugares.

Porém, sabendo que ações ad hoc são insustentáveis no tempo, depreende-se dessa experiência a certeza de que resultados de longo prazo só poderão ser obtidos se, como reiteradamente destacado, enfrentarmos estruturalmente alguns temas sensíveis, como: a distribuição e a articulação de competências entre União, estados e municípios e a criação de mecanismos efetivos de cooperação entre eles e demais poderes e ministérios públicos; a reforma do modelo policial e de investigação estabelecido pela Constituição; o financiamento da área; e o estabelecimento de requisitos mínimos nacionais para as instituições de segurança pública no que diz respeito à formação dos profissionais, carreiras, transparência e prestação de contas, uso da força e controle externo.

Hoje temos polícias com acesso às mais modernas ferramentas tecnológicas e formadas por homens e mulheres altamente qualificados e com grande preparo intelectual, muitos com disposição para inovar e construir padrões de policiamento mais eficientes em contextos 
democráticos. Entretanto, vale frisar que, como pano de fundo, há uma enorme disputa pelo significado de lei, ordem e segurança pública em curso. Sem que assumamos essa disputa não conseguiremos dizer claramente quais são os mandatos outorgados às instituições de justiça e segurança e, consequentemente, pouco avançaremos na construção de políticas públicas mais eficientes.

O Brasil, ao largo do notável aprimoramento técnico operacional dos últimos vinte anos, ainda se impõe um silêncio obsequioso frente ao problema da segurança pública, que nos desafia a pensar em um projeto de reforma das polícias que as valorizem como uma instituição central do Estado democrático de direito e da cidadania.

As polícias, bem como as demais instituições da área, retratam a forma como o Brasil optou por administrar conflitos sociais e de se conceber como nação. Assim, falar hoje de segurança pública significa falar de um projeto de país; significa ter coragem política e institucional para liderar um pacto pela promoção de uma vida digna e em paz para parcelas majoritárias da população. 


\section{GRÁFICOS E TABELAS}

GRÁfico 1 - Evolução dA TAXa de MORTALIDAde POR AGRESSÃo (Brasil, 1990-2013)

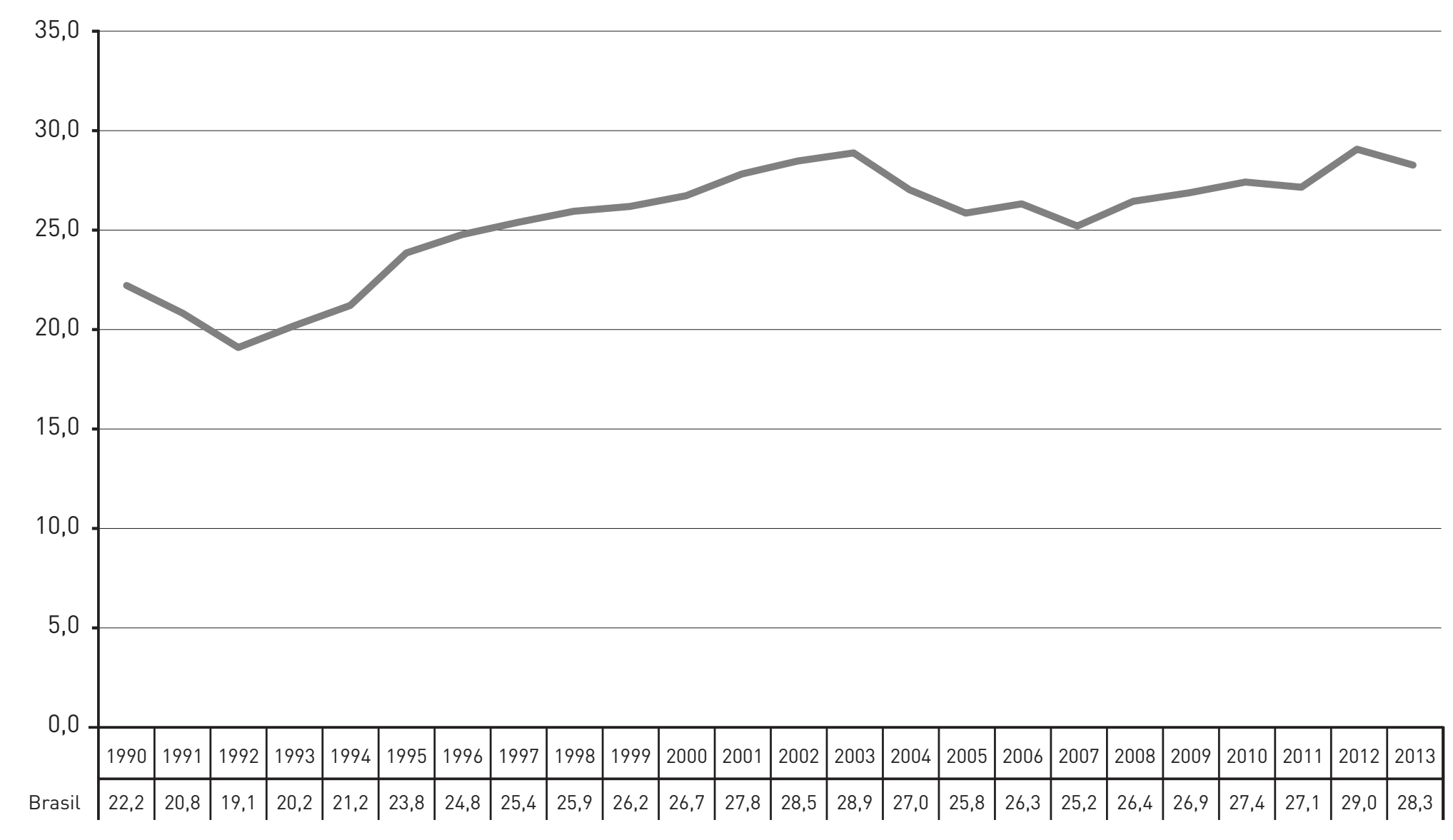

Fonte: Instituto Brasileiro de Geografia e Estatística (IBGE); MS/SVS/DASIS - Sistema de Informações sobre Mortalidade (SIM); Fórum Brasileiro de Segurança Pública. 
tabela 1 - Mortes POR Agressão (BRasil E UnidAdes da FEDERAÇÃO, 1990-2013)

\begin{tabular}{|c|c|c|c|c|c|c|c|c|c|c|c|}
\hline Unidade da federação & 1990 & 1991 & 1992 & 1993 & 1994 & 1995 & 1996 & 1997 & 1998 & 1999 & 2000 \\
\hline Brasil & 22,2 & 20,8 & 19,1 & 20,2 & 21,2 & 23,8 & 24,8 & 25,4 & 25,9 & 26,2 & 26,7 \\
\hline Acre & 15,8 & 25,1 & 24,7 & 26,1 & 19,7 & 22,6 & 21,1 & 20,0 & 21,2 & 9,7 & 19,4 \\
\hline Alagoas & 29,2 & 26,8 & 23,3 & 23,8 & 23,3 & 27,2 & 28,1 & 24,1 & 21,8 & 20,3 & 25,6 \\
\hline Amapá & 16,5 & 18,0 & 23,9 & 21,0 & 38,4 & 38,3 & 43,2 & 34,1 & 38,7 & 43,9 & 32,5 \\
\hline Amazonas & 18,1 & 19,1 & 16,2 & 15,6 & 16,8 & 18,3 & 18,8 & 19,0 & 21,3 & 20,4 & 19,8 \\
\hline Bahia & 7,5 & 4,9 & 6,9 & 12,2 & 14,0 & 12,1 & 15,0 & 15,5 & 9,7 & 6,8 & 9,4 \\
\hline Ceará & 8,8 & 9,7 & 8,4 & 10,7 & 9,5 & 12,6 & 13,0 & 14,8 & 13,4 & 15,6 & 16,5 \\
\hline Distrito Federal & 31,1 & 33,3 & 28,3 & 36,1 & 35,8 & 39,5 & 38,3 & 35,6 & 37,4 & 36,7 & 37,5 \\
\hline Espírito Santo & 35,3 & 37,5 & 32,0 & 40,9 & 42,8 & 41,7 & 42,8 & 50,0 & 58,4 & 52,5 & 46,8 \\
\hline Goiás & 16,9 & 20,3 & 19,2 & 16,7 & 17,4 & 17,0 & 15,6 & 15,0 & 13,4 & 16,5 & 20,2 \\
\hline Maranhão & 9,1 & 9,2 & 8,4 & 7,8 & 6,0 & 7,3 & 6,7 & 6,0 & 5,0 & 4,6 & 6,1 \\
\hline Mato Grosso & 21,0 & 22,2 & 17,2 & 16,5 & 14,2 & 25,9 & 29,5 & 33,5 & 36,3 & 34,7 & 39,8 \\
\hline Mato Grosso do Sul & 20,3 & 22,0 & 23,5 & 24,8 & 27,3 & 32,7 & 37,7 & 37,4 & 33,5 & 28,2 & 31,0 \\
\hline Minas Gerais & 7,5 & 7,7 & 6,9 & 7,4 & 6,7 & 7,2 & 7,3 & 7,7 & 8,6 & 8,9 & 11,5 \\
\hline Pará & 15,5 & 16,4 & 15,1 & 12,0 & 13,4 & 12,8 & 12,5 & 13,2 & 13,3 & 10,8 & 13,0 \\
\hline Paraíba & 13,7 & 12,4 & 10,6 & 11,1 & 11,9 & 13,6 & 19,0 & 14,7 & 13,5 & 12,0 & 15,1 \\
\hline Paraná & 14,1 & 14,5 & 12,8 & 14,4 & 14,6 & 15,9 & 15,3 & 17,3 & 17,6 & 18,1 & 18,5 \\
\hline Pernambuco & 39,1 & 38,7 & 35,3 & 37,6 & 34,9 & 36,4 & 40,7 & 49,7 & 58,9 & 55,4 & 54,0 \\
\hline Piauí & 4,5 & 4,4 & 3,7 & 4,6 & 3,8 & 4,4 & 4,7 & 5,7 & 5,2 & 4,8 & 8,2 \\
\hline Rio de Janeiro & 56,1 & 39,5 & 35,0 & 41,0 & 48,7 & 61,9 & 60,0 & 58,8 & 55,3 & 52,5 & 51,0 \\
\hline Rio Grande do Norte & 8,6 & 9,1 & 8,1 & 9,7 & 8,2 & 9,6 & 9,3 & 9,1 & 8,5 & 8,5 & 9,0 \\
\hline Rio Grande do Sul & 18,7 & 18,4 & 16,9 & 12,5 & 14,0 & 14,9 & 15,2 & 16,7 & 15,3 & 15,3 & 16,3 \\
\hline Rondônia & 51,3 & 43,6 & 34,6 & 39,8 & 30,7 & 24,4 & 24,5 & 28,4 & 38,3 & 33,5 & 33,8 \\
\hline Roraima & 61,3 & 36,3 & 43,1 & 29,9 & 31,0 & 33,6 & 43,3 & 35,4 & 50,6 & 57,7 & 39,5 \\
\hline Santa Catarina & 8,4 & 7,8 & 7,5 & 7,6 & 7,1 & 8,4 & 8,3 & 8,4 & 7,9 & 7,5 & 7,9 \\
\hline São Paulo & 30,8 & 30,7 & 28,2 & 28,2 & 30,1 & 34,3 & 36,2 & 36,1 & 39,7 & 44,1 & 42,2 \\
\hline Sergipe & 10,1 & 21,6 & 30,5 & 20,2 & 21,9 & 16,0 & 14,7 & 11,5 & 10,4 & 19,7 & 23,3 \\
\hline Tocantins & 5,9 & 10,1 & 7,1 & 9,6 & 10,8 & 7,4 & 12,2 & 11,2 & 12,3 & 13,0 & 15,5 \\
\hline
\end{tabular}




\begin{tabular}{|c|c|c|c|c|c|c|c|c|c|c|c|c|}
\hline 2001 & 2002 & 2003 & 2004 & 2005 & 2006 & 2007 & 2008 & 2009 & 2010 & 2011 & 2012 & 2013 \\
\hline 27,8 & 28,5 & 28,9 & 27,0 & 25,8 & 26,3 & 25,2 & 26,4 & 26,9 & 27,4 & 27,1 & 29,0 & 28,3 \\
\hline 21,2 & 25,7 & 22,5 & 18,7 & 18,7 & 22,6 & 18,9 & 19,6 & 22,0 & 22,5 & 22,5 & 27,5 & 31,0 \\
\hline 29,3 & 34,3 & 35,7 & 35,1 & 40,2 & 53,0 & 59,6 & 60,3 & 59,3 & 66,8 & 72,2 & 64,6 & 65,5 \\
\hline 36,9 & 35,0 & 35,5 & 31,3 & 33,0 & 33,0 & 26,9 & 34,4 & 30,5 & 38,5 & 30,4 & 35,9 & 29,8 \\
\hline 16,7 & 17,3 & 18,5 & 16,9 & 18,5 & 21,1 & 21,0 & 24,8 & 27,0 & 30,9 & 36,4 & 36,7 & 31,1 \\
\hline 11,9 & 13,0 & 16,0 & 16,6 & 20,4 & 23,5 & 25,7 & 32,9 & 36,8 & 41,1 & 38,7 & 41,9 & 36,8 \\
\hline 17,2 & 18,9 & 20,1 & 20,0 & 20,9 & 21,8 & 23,2 & 24,0 & 25,4 & 31,8 & 32,7 & 44,6 & 50,9 \\
\hline 36,9 & 34,7 & 39,1 & 36,5 & 31,9 & 32,3 & 33,5 & 34,1 & 38,6 & 34,3 & 37,4 & 38,9 & 32,9 \\
\hline 46,7 & 51,2 & 50,5 & 49,4 & 46,9 & 51,2 & 53,6 & 56,4 & 57,2 & 51,0 & 47,4 & 47,3 & 42,4 \\
\hline 21,5 & 24,5 & 23,7 & 26,4 & 24,9 & 24,6 & 24,4 & 30,0 & 30,2 & 31,6 & 36,4 & 44,3 & 45,2 \\
\hline 9,4 & 9,9 & 13,0 & 11,7 & 14,8 & 15,0 & 17,4 & 19,7 & 21,8 & 22,7 & 23,7 & 26,0 & 31,4 \\
\hline 38,5 & 37,0 & 35,0 & 32,1 & 32,4 & 31,5 & 30,7 & 31,8 & 33,3 & 32,2 & 32,3 & 34,3 & 36,8 \\
\hline 29,3 & 32,4 & 32,7 & 29,6 & 27,7 & 29,5 & 30,0 & 29,5 & 30,8 & 26,1 & 27,0 & 27,1 & 24,0 \\
\hline 12,9 & 16,2 & 20,6 & 22,6 & 21,9 & 21,3 & 20,8 & 19,5 & 18,5 & 18,5 & 21,5 & 22,8 & 22,8 \\
\hline 15,1 & 18,4 & 21,0 & 22,7 & 27,6 & 29,2 & 30,4 & 39,2 & 40,3 & 46,7 & 40,0 & 41,7 & 43,0 \\
\hline 14,1 & 17,4 & 17,6 & 18,6 & 20,6 & 22,6 & 23,6 & 27,3 & 33,7 & 38,7 & 42,7 & 40,1 & 39,6 \\
\hline 21,0 & 22,7 & 25,5 & 28,1 & 29,0 & 29,8 & 29,6 & 32,6 & 34,6 & 34,5 & 31,7 & 32,7 & 26,6 \\
\hline 58,7 & 54,8 & 55,3 & 50,7 & 51,2 & 52,7 & 53,1 & 50,7 & 44,9 & 39,2 & 39,1 & 37,1 & 33,9 \\
\hline 9,7 & 10,9 & 10,8 & 11,8 & 12,8 & 14,4 & 13,2 & 12,4 & 12,7 & 13,8 & 14,7 & 17,2 & 19,1 \\
\hline 50,5 & 56,5 & 52,7 & 49,2 & 46,1 & 45,8 & 40,1 & 34,0 & 31,7 & 32,9 & 28,3 & 28,3 & 29,9 \\
\hline 11,2 & 10,6 & 14,2 & 11,7 & 13,6 & 14,8 & 19,3 & 23,2 & 25,2 & 25,7 & 32,6 & 34,7 & 43,0 \\
\hline 17,9 & 18,3 & 18,1 & 18,5 & 18,6 & 17,9 & 19,6 & 21,8 & 20,4 & 19,3 & 19,2 & 21,9 & 20,7 \\
\hline 40,1 & 42,3 & 38,4 & 38,0 & 36,0 & 37,7 & 27,4 & 32,1 & 35,6 & 34,8 & 28,4 & 32,9 & 27,6 \\
\hline 31,7 & 34,9 & 29,7 & 22,6 & 24,0 & 27,3 & 27,9 & 25,4 & 27,8 & 27,3 & 20,6 & 35,4 & 43,8 \\
\hline 8,4 & 10,3 & 11,6 & 11,1 & 10,5 & 11,0 & 10,4 & 13,0 & 13,1 & 13,0 & 12,6 & 12,8 & 11,6 \\
\hline 41,8 & 38,0 & 35,9 & 28,6 & 21,6 & 19,9 & 15,0 & 14,9 & 15,3 & 14,1 & 13,5 & 15,1 & 13,4 \\
\hline 29,3 & 29,7 & 25,2 & 24,4 & 25,0 & 29,8 & 25,9 & 28,7 & 32,8 & 33,4 & 35,4 & 41,8 & 43,6 \\
\hline 18,8 & 14,9 & 18,3 & 16,4 & 15,5 & 17,7 & 16,5 & 18,1 & 22,0 & 22,6 & 25,5 & 26,2 & 23,1 \\
\hline
\end{tabular}

Fonte: Instituto Brasileiro de Geografia e Estatística (IBGE); MS/SVS/DASIS - Sistema de Informações sobre Mortalidade (SIM); Fórum Brasileiro de Segurança Pública. 
GRÁfico 2 - Mortes DeCorrentes de interVenção POlicial (SÃo PaUlo E Rio DE JANEIRO, 1998-2014)

RESISTÊNCIA SEGUIDA DE MORTE / AUTOS DE RESISTÊNCIA

SÃO PAULO E RIO DE JANEIRO (1998-2014)

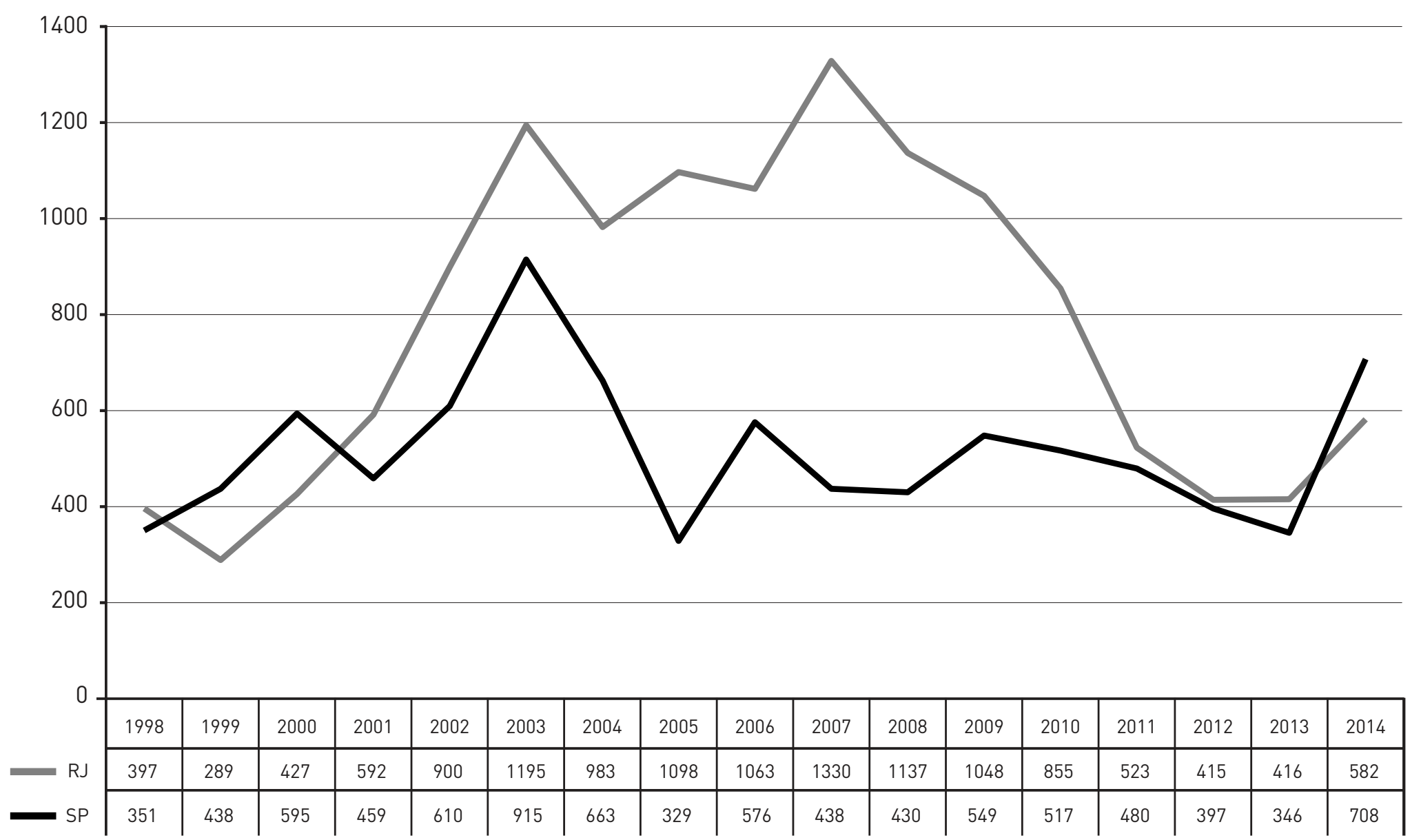

Fontes: Instituto de Segurança Pública do Rio de Janeiro; Cesec; SSP/SP; Datasus. 


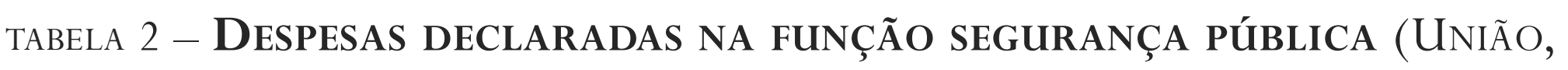
UNIDADES DA FEDERAÇÃO E MUNICÍPIOS, 2002-2014)

\begin{tabular}{llll} 
ANO & UNIÃo & UNIDADES DA FEDERAC̣ÃO & MUNICÍPIOS \\
\hline 2002 & $4.556 .427 .528,16$ & $39.312 .094 .231,84$ & $1.311 .595 .176,10$ \\
2003 & $4.337 .467 .169,57$ & $35.176 .992 .850,23$ & $1.350 .242 .893,93$ \\
2004 & $4.682 .702 .873,91$ & $33.814 .961 .151,87$ & $1.546 .040 .282,49$ \\
2005 & $4.777 .776 .385,55$ & $36.087 .705 .500,76$ & $1.589 .651 .484,75$ \\
2006 & $5.241 .692 .260,14$ & $41.595 .429 .887,43$ & $1.854 .946 .206,28$ \\
2007 & $6.001 .080 .724,75$ & $44.155 .483 .448,62$ & $2.101 .191 .174,59$ \\
2008 & $6.834 .490 .750,64$ & $46.546 .606 .457,43$ & $2.454 .725 .378,80$ \\
2009 & $7.750 .831 .169,00$ & $50.713 .785 .343,92$ & $2.668 .080 .572,32$ \\
2010 & $9.186 .450 .672,63$ & $47.728 .451 .280,37$ & $2.970 .786 .104,33$ \\
2011 & $8.207 .619 .418,44$ & $54.087 .445 .776,90$ & $3.460 .581 .448,48$ \\
2012 & $8.826 .499 .707,56$ & $50.309 .944 .661,87$ & $3.900 .798 .913,53$ \\
2013 & $8.724 .788 .734,63$ & $51.970 .178 .973,76$ & $3.793 .220 .468,90$ \\
2014 & $8.057 .404 .000,00$ & $59.305 .236 .705,05$ & $3.900 .289 .605,73$
\end{tabular}

Fonte: Secretaria do Tesouro Nacional; SIAFI - STN/CCONT/GEINC; Finbra; Instituto Brasileiro de Geografia e Estatística (IBGE); Fórum Brasileiro de Segurança Pública.

Nota: Corrigido pela IPCA, valores de dezembro de 2014. 
GRÁfico 3 - PARTICIPAÇÃo dAs DESPESAS DEClARAdAS NA FUnÇÃo SEGURANÇA PÚBLICA (UNIÃO, UNIDADES DA FEDERAÇÃO E MUNICÍPIOS, 2002-2014)

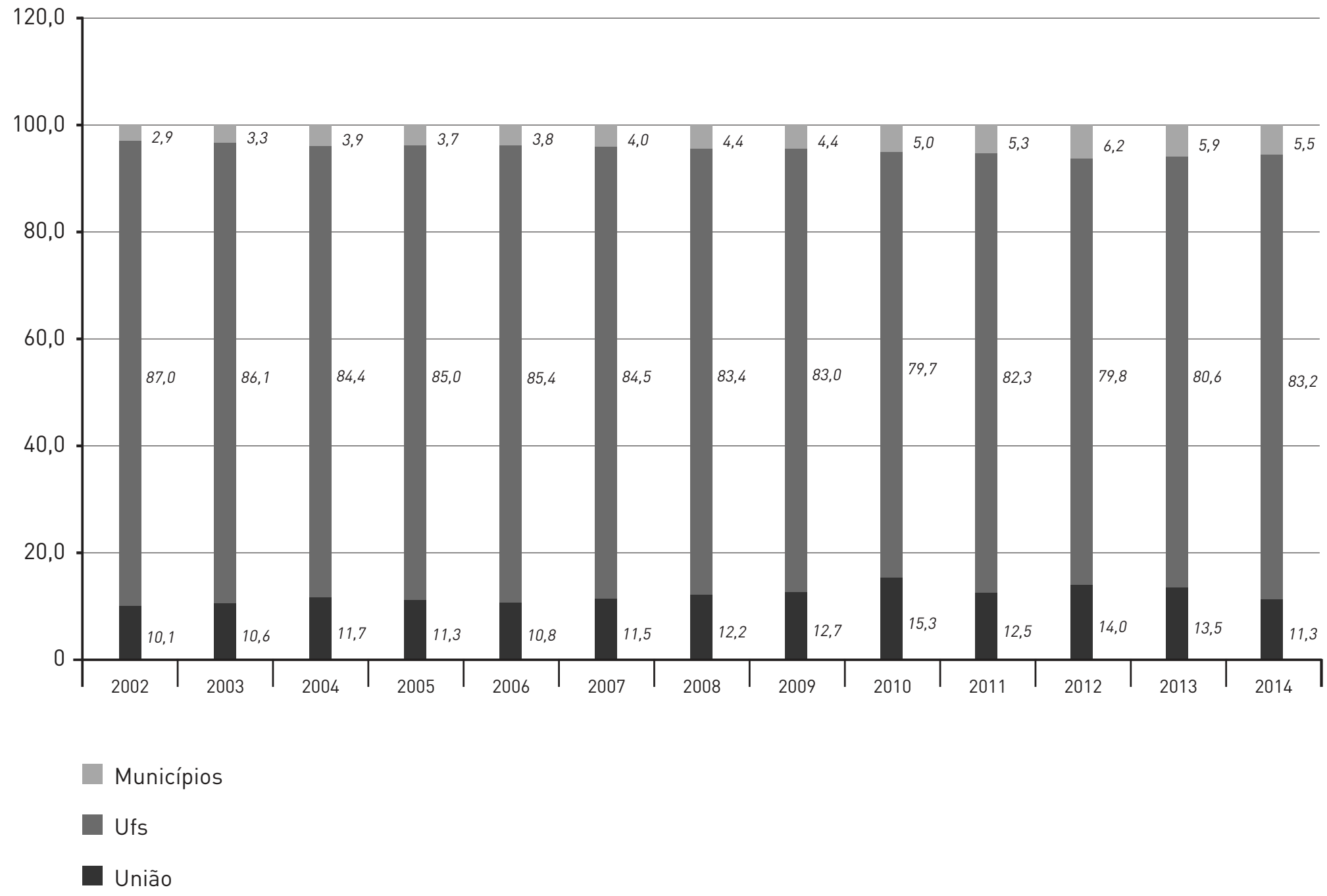

Fonte: Secretaria do Tesouro Nacional; SIAFI - STN/CCONT/GEINC; Finbra; Instituto Brasileiro de Geografia e Estatística (IBGE); Fórum Brasileiro de Segurança Pública. 
TABEla 3 - EFETIVO POLICIAL - POlícia Militar, POlícia CIVIL E GUARDA

MUNICIPAL (BRASIL E UNIDADES DA FEDERAÇÃO, 2014)

\begin{tabular}{|c|c|c|c|}
\hline BRASIL E UNIDADES DA FEDERAÇÃO & POLÍCIA MILITAR & POLÍCIA CIVIL & GUARDA MUNICIPAL \\
\hline Brasil & 425.248 & 117.642 & 99.354 \\
\hline Acre & 2.712 & 1.086 & - \\
\hline Alagoas & 7.135 & 2.181 & 2792 \\
\hline Amapá & 3.700 & 1.102 & 765 \\
\hline Amazonas & 9.050 & 2.263 & 1740 \\
\hline Bahia & 31.039 & 5.660 & 9617 \\
\hline Ceará & 15.926 & 2.576 & 4267 \\
\hline Distrito Federal & 14.345 & 4.586 & - \\
\hline Espírito Santo & 8.491 & 2.485 & 1536 \\
\hline Goiás & 11.950 & 3.039 & 2979 \\
\hline Maranhão & 7.709 & 2.034 & 2567 \\
\hline Mato Grosso & 6.579 & 2.386 & 258 \\
\hline Mato Grosso do Sul & 5.255 & 1.937 & 1822 \\
\hline Minas Gerais & 42.115 & 9.744 & 5069 \\
\hline Pará & 15.943 & 2.766 & 3264 \\
\hline Paraíba & 9.263 & 1.802 & 2126 \\
\hline Paraná & 17.465 & 4.649 & 4136 \\
\hline Pernambuco & 19.348 & 6.015 & 5370 \\
\hline Piauí & 5.335 & 1.535 & 181 \\
\hline Rio de Janeiro & 46.135 & 10.587 & 16976 \\
\hline Rio Grande do Norte & 8.926 & 1.929 & 1272 \\
\hline Rio Grande do Sul & 20.405 & 5.540 & 2832 \\
\hline Rondônia & 5.200 & 2.427 & 47 \\
\hline Roraima & 1.669 & 859 & 271 \\
\hline Santa Catarina & 11.560 & 3.191 & 644 \\
\hline São Paulo & 89.478 & 32.278 & 27038 \\
\hline Sergipe & 4.660 & 1.306 & 1448 \\
\hline Tocantins & 3.855 & 1.679 & 337 \\
\hline
\end{tabular}

Fonte: Pesquisa de Informações Básicas Estaduais; Pesquisa de Informações Básicas Municipais; Perfil dos Estados e Municípios Brasileiros (IBGE); Anuário Brasileiro de Segurança Pública.

(-) Fenômeno inexistente. 
TABEla 4 - DistribuiçÃo dos PRESOS NO SiSTEMA PENiTENCIÁRIO, POR SitUAÇÃo

PRISIONAL (BRASIL E UNIDADES DA FEDERAÇÃO, 2013-2014)

\begin{tabular}{|c|c|c|c|c|c|c|}
\hline \multirow{2}{*}{$\begin{array}{l}\text { BRASIL E UNIDADES } \\
\text { DA FEDERAC̣ÃO }\end{array}$} & \multicolumn{2}{|c|}{ CONDENADOS (EM \%) } & \multicolumn{2}{|c|}{$\begin{array}{l}\text { SOB MEDIDA DE } \\
\text { SEGURANÇA (EM \%) }\end{array}$} & \multicolumn{2}{|c|}{ PROVISÓRIOS (EM \%) } \\
\hline & 2013 & 2014 & 2013 & 2014 & 2013 & 2014 \\
\hline Brasil & 59,2 & 61,2 & 0,7 & 0,5 & 40,1 & 38,3 \\
\hline Acre & 66,9 & 80,6 & 0,3 & 0,1 & 32,8 & 19,2 \\
\hline Alagoas & 62,7 & 60,9 & 1,1 & 0,7 & 36,2 & 38,3 \\
\hline Amapá & 59,3 & 68,7 & 0,3 & 0,7 & 40,4 & 30,7 \\
\hline Amazonas & 33,5 & 43,3 & 0,3 & 0,1 & 66,2 & 56,6 \\
\hline Bahia & 46,9 & 44,7 & 0,3 & 0,4 & 52,9 & 54,9 \\
\hline Ceará & 54,2 & 52,5 & 0,6 & 0,5 & 45,2 & 47,0 \\
\hline Distrito Federal & 76,7 & 71,7 & 0,5 & 0,6 & 22,8 & 27,7 \\
\hline Espírito Santo & 52,5 & 55,3 & 0,3 & 0,4 & 47,3 & 44,3 \\
\hline Goiás & 56,4 & 51,1 & 0,1 & 0,2 & 43,6 & 48,6 \\
\hline Maranhão & 42,3 & 45,2 & 0,0 & 0,0 & 57,7 & 54,8 \\
\hline Mato Grosso & 48,5 & 47,0 & 0,2 & 0,2 & 51,3 & 52,8 \\
\hline Mato Grosso do Sul & 74,0 & 74,5 & 0,2 & 0,3 & 25,8 & 25,2 \\
\hline Minas Gerais & 39,9 & 51,0 & 0,3 & 0,3 & 59,8 & 48,7 \\
\hline Pará & 52,0 & 53,1 & 1,1 & 1,0 & 46,9 & 45,9 \\
\hline Paraíba & 60,9 & 61,9 & 1,0 & 0,9 & 38,1 & 37,2 \\
\hline Paraná & 81,2 & 72,8 & 2,2 & 1,7 & 16,6 & 25,5 \\
\hline Pernambuco & 36,1 & 40,9 & 1,6 & - & 62,3 & 59,1 \\
\hline Piauí & 32,6 & 35,8 & 0,7 & 0,7 & 66,7 & 63,6 \\
\hline Rio de Janeiro & 57,5 & 53,6 & 0,3 & 0,6 & 42,2 & 45,9 \\
\hline Rio Grande do Norte & 72,3 & 65,8 & 1,7 & 1,2 & 26,0 & 33,0 \\
\hline Rio Grande do Sul & 71,8 & 64,8 & 1,5 & 0,3 & 26,7 & 34,8 \\
\hline Rondônia & 80,7 & 83,2 & 0,5 & 0,4 & 18,9 & 16,4 \\
\hline Roraima & 65,1 & 49,7 & - & - & 34,9 & 50,3 \\
\hline Santa Catarina & 71,7 & 74,2 & 0,6 & 0,5 & 27,6 & 25,3 \\
\hline São Paulo & 64,5 & 68,7 & 0,7 & 0,5 & 34,7 & 30,8 \\
\hline Sergipe & 40,2 & 28,1 & 1,4 & 1,0 & 58,4 & 70,9 \\
\hline Tocantins & 48,1 & 55,2 & 0,7 & 0,4 & 51,2 & 44,4 \\
\hline
\end{tabular}

Fonte: Ministério da Justiça/Departamento Penitenciário Nacional (Depen); referências: jun. / 2013 e jun./2014; Fórum Brasileiro de Segurança Pública; Anuário Brasileiro de Segurança Pública.

(-) Fenômeno inexistente. 
TABela 5 - Presos no Sistema Penitenciário, VAGAS EXisTentes e déficit de VAGAS (BRASIL E UNIDADES DA FEDERAÇÃO, 2013-2014)

\begin{tabular}{|c|c|c|c|c|c|c|c|c|}
\hline \multirow{2}{*}{$\begin{array}{l}\text { BRASIL E UNIDADES } \\
\text { DA FEDERAC̣Ã̃o }\end{array}$} & \multicolumn{2}{|l|}{ PRESOS } & \multicolumn{2}{|c|}{$\begin{array}{l}\text { VAGAS } \\
\text { EXISTENTES }\end{array}$} & \multicolumn{2}{|c|}{$\begin{array}{l}\text { RAZÃO } \\
\text { PRESOS/VAGAS }\end{array}$} & \multicolumn{2}{|c|}{$\begin{array}{l}\text { DÉFICIT/ } \\
\text { SUPERÁVIT DE VAGAS }\end{array}$} \\
\hline & 2013 & 2014 & 2013 & 2014 & 2013 & 2014 & 2013 & 2014 \\
\hline Brasil & 537.790 & 579.423 & 317.733 & 375.892 & 1,7 & 1,5 & -220.057 & -203.531 \\
\hline Acre & 3.817 & 3.488 & 1.858 & 2.258 & 2,1 & 1,5 & -1.959 & -1.230 \\
\hline Alagoas & 4.536 & 5.423 & 1.575 & 2.589 & 2,9 & 2,1 & -2.961 & -2.834 \\
\hline Amapá & 2.232 & 2.654 & 850 & 1.898 & 2,6 & 1,4 & -1.382 & -756 \\
\hline Amazonas & 7.407 & 7.378 & 3.291 & 3.385 & 2,3 & 2,2 & -4.116 & -3.993 \\
\hline Bahia & 11.808 & 11.836 & 8.359 & 8.321 & 1,4 & 1,4 & -3.449 & -3.515 \\
\hline Ceará & 18.466 & 20.416 & 11.264 & 11.790 & 1,6 & 1,7 & -7.202 & -8.626 \\
\hline Distrito Federal & 12.067 & 13.269 & 6.513 & 6.605 & 1,9 & 2,0 & -5.554 & -6.664 \\
\hline Espírito Santo & 14.883 & 16.234 & 11.586 & 12.905 & 1,3 & 1,3 & -3.297 & -3.329 \\
\hline Goiás & 12.074 & 13.244 & 7.780 & 8.491 & 1,6 & 1,6 & -4.294 & -4.753 \\
\hline Maranhão & 4.921 & 4.530 & 2.615 & 5.049 & 1,9 & 0,9 & -2.306 & 519 \\
\hline Mato Grosso & 11.303 & 10.357 & 5.918 & 8.264 & 1,9 & 1,3 & -5.385 & -2.093 \\
\hline Mato Grosso do Sul & 12.004 & 14.203 & 6.701 & 6.902 & 1,8 & 2,1 & -5.303 & -7.301 \\
\hline Minas Gerais & 48.143 & 56.236 & 31.634 & 37.323 & 1,5 & 1,5 & -16.509 & -18.913 \\
\hline Pará & 11.401 & 12.604 & 7.283 & 9.021 & 1,6 & 1,4 & -4.118 & -3.583 \\
\hline Paraíba & 8.958 & 9.596 & 5.391 & 6.298 & 1,7 & 1,5 & -3.567 & -3.298 \\
\hline Paraná & 17.150 & 19.511 & 14.913 & 19.300 & 1,2 & 1,0 & -2.237 & -211 \\
\hline Pernambuco & 30.894 & 31.510 & 11.557 & 11.894 & 2,7 & 2,6 & -19.337 & -19.616 \\
\hline Piauí & 2.955 & 3.224 & 2.238 & 1.718 & 1,3 & 1,9 & -717 & -1.506 \\
\hline Rio de Janeiro & 32.944 & 39.321 & 25.558 & 28.230 & 1,3 & 1,4 & -7.386 & -11.091 \\
\hline Rio Grande do Norte & 4.696 & 7.047 & 3.946 & 4.502 & 1,2 & 1,6 & -750 & -2.545 \\
\hline Rio Grande do Sul & 28.743 & 28.059 & 21.425 & 23.165 & 1,3 & 1,2 & -7.318 & -4.894 \\
\hline
\end{tabular}


ESTADO, POLÍCIAS E SEGURANÇA PÚBLICA NO BRASIL :

\begin{tabular}{|c|c|c|c|c|c|c|c|c|}
\hline Rondônia & 7.720 & 7.631 & 4.928 & 5.996 & 1,6 & 1,3 & -2.792 & -1.635 \\
\hline Roraima & 1.528 & 1.605 & 1.140 & 1.080 & 1,3 & 1,5 & -388 & -525 \\
\hline Santa Catarina & 17.423 & 17.914 & 9.973 & 13.596 & 1,7 & 1,3 & -7.450 & -4.318 \\
\hline São Paulo ${ }^{1}$ & 202.747 & 214.843 & 105.384 & 130.449 & 1,9 & 1,6 & -97.363 & -84.394 \\
\hline Sergipe & 4.597 & 4.057 & 2.265 & 2.579 & 2,0 & 1,6 & -2.332 & -1.478 \\
\hline Tocantins & 2.373 & 3.233 & 1.788 & 2.284 & 1,3 & 1,4 & -585 & -949 \\
\hline
\end{tabular}

Fonte: Ministério da Justiça/Departamento Penitenciário Nacional (Depen); Anuário Brasileiro de Segurança Pública; Fórum Brasileiro de Segurança Pública. Referências: jun./2013 e jun./2014.

1 Os dados do estado de São Paulo foram coletados no website da Secretaria de Administração Penitenciária, que não preencheu o questionário do Infopen. 
QUADRO 1 - EXEMPLOS DE AÇÕES INCREMENTAIS E COM FOCO NA PARTICIPAÇÃO SOCIAL, NA GESTÃO POLICIAL E NA GESTÃO DA INFORMAÇÃO EM SEGURANÇA PÚBLICA NO PAÍS

\begin{tabular}{|c|c|c|c|c|}
\hline EIXOS & DÉCADA DE 1980 & DÉCADA DE 1990 & DÉCADA DE 2000 & DÉCADA DE 2010 \\
\hline \multirow{7}{*}{$\begin{array}{l}\text { Participação social, } \\
\text { controle e direitos } \\
\text { humanos }\end{array}$} & \multirow{7}{*}{$\begin{array}{l}\text { Criação das } \\
\text { primeiras } \\
\text { Delegacias } \\
\text { de Defesa } \\
\text { da Mulher } \\
\text { (SP, 1986). }\end{array}$} & $\begin{array}{l}\text { Disque Denúncia } \\
\text { (RJ, 1995). }\end{array}$ & $\begin{array}{l}\text { Disque Denúncia } \\
\text { (SP, 2000). }\end{array}$ & \multirow{7}{*}{$\begin{array}{l}\text { Protagonismo } \\
\text { da SDH nos assuntos } \\
\text { relacionados } \\
\text { às violações de } \\
\text { direitos humanos } \\
\text { por parte dos } \\
\text { agentes de } \\
\text { segurança pública. }\end{array}$} \\
\hline & & $\begin{array}{l}\text { Criação da primeira } \\
\text { Ouvidoria de Polícia } \\
\text { (SP, 1995). }\end{array}$ & $\begin{array}{l}\text { Criação dos } \\
\text { Gabinetes de } \\
\text { Gestão Integrada } \\
\text { (GGI) e GGIMs } \\
\text { (Municipais) (2003). }\end{array}$ & \\
\hline & & $\begin{array}{l}10 \text { Plano Nacional } \\
\text { de Direitos } \\
\text { Humanos (1996). }\end{array}$ & $\begin{array}{l}2^{\circ} \text { e } 3^{\circ} \text { Plano } \\
\text { Nacional de } \\
\text { Direitos Humanos } \\
\text { (2002 e 2009). }\end{array}$ & \\
\hline & & $\begin{array}{l}\text { Criação do } \\
\text { Programa de } \\
\text { Acompanhamento } \\
\text { de Policiais } \\
\text { Envolvidos em } \\
\text { Ocorrências de } \\
\text { Alto Risco (Proar) } \\
\text { (SP, 1996). }\end{array}$ & $\begin{array}{l}\text { 1a Conferência } \\
\text { Nacional de } \\
\text { Segurança } \\
\text { Pública (2009). }\end{array}$ & \\
\hline & & $\begin{array}{l}\text { Implantação do } \\
\text { Método Giraldi, } \\
\text { de Tiro Defensivo, } \\
\text { pela Polícia Militar } \\
\text { de São Paulo (1998). }\end{array}$ & & \\
\hline & & $\begin{array}{l}\text { Criação dos } \\
\text { Conselhos de } \\
\text { Segurança (o } \\
\text { primeiro foi criado } \\
\text { em Maringá, Paraná, } \\
\text { em 1994). }\end{array}$ & & \\
\hline & & $\begin{array}{l}\text { Criação da Secretaria } \\
\text { de Direitos Humanos } \\
\text { (SDH) (1997). }\end{array}$ & & \\
\hline $\begin{array}{l}\text { Gestão das polícias } \\
\text { e envolvimento de } \\
\text { novos atores }\end{array}$ & $\begin{array}{l}\text { Desenvolvimento } \\
\text { das primeiras } \\
\text { estratégias de } \\
\text { policiamento } \\
\text { comunitário. }\end{array}$ & $\begin{array}{l}\text { Implementação da } \\
\text { filosofia de } \\
\text { policiamento } \\
\text { comunitário em } \\
\text { diversos territórios } \\
\text { (SP, 1997). }\end{array}$ & $\begin{array}{l}\text { Criação do Programa } \\
\text { Ronda no Quarteirão, } \\
\text { no Ceará (2008), e da } \\
\text { Unidade de Polícia } \\
\text { Pacificadora (UPP), } \\
\text { no Rio de Janeiro } \\
\text { (2008), ambos } \\
\text { inspirados nos } \\
\text { padrões de } \\
\text { policiamento } \\
\text { comunitário. }\end{array}$ & $\begin{array}{l}\text { MJ sanciona } \\
\text { primeira portaria } \\
\text { com diretrizes } \\
\text { sobre o uso da } \\
\text { força pelos agentes } \\
\text { de segurança } \\
\text { pública (2010). }\end{array}$ \\
\hline
\end{tabular}


$1^{\circ}$ e $2^{\circ}$ Plano

Nacional de

Segurança Pública

(2000 e 2003).

Criação da Secretaria Proposta de Criação

Nacional de Segurança do Sistema Único de

Pública (Senasp) (1997). Segurança Pública

(Susp) (2003).

Fundo Nacional de

Segurança Pública

(2001).

Modernização da

Polícia Federal (2003).

\begin{tabular}{ll}
\hline $\begin{array}{l}\text { Experiência de } \\
\text { Programa de }\end{array}$ & $\begin{array}{l}\text { Programa de } \\
\text { integração das } \\
\text { áreas de jurisdição } \\
\text { das polícias no Rio }\end{array}$ \\
$\begin{array}{l}\text { de Janeiro (1997), } \\
\text { com Cidadania } \\
\text { em São Paulo }\end{array}$ & $\begin{array}{l}\text { Desenho e } \\
\text { implantação de }\end{array}$ \\
(1998), no Ceará & Protocolos \\
(1999) e no Pará & Operacionais Padrão \\
(POPs) (SP e União).
\end{tabular}

(1995).

\section{Criação do Infoseg pela União (1995).}

União (1995).
Criação do Projeto
Delegacia Legal
(RJ, 1996).

Implantação de projetos de integração baseados em metas e monitoramento (Fica Vivo!, $M G, 2001$ ).

Criação do Sistema Nacional de Segurança Pública e Justiça Criminal (SinespJC) (2004).
Criação do Infocrim (SP, 1999).

Lançamento dos primeiros editais de Pesquisas Aplicadas em Justiça Criminal e Segurança Pública pela Senasp (2004).

Criação dos primeiros sistemas estaduais de estatísticas criminais (Lei n. 9.155/95, SP; Instituto de Segurança Pública, RJ, 1999)

\section{Criação da Rede de} Altos Estudos em Segurança Pública (Renaesp) (2006).
Novas experiências de integração das polícias baseadas em metas, indicadores e monitoramento no Espírito Santo (Estado Presente) e em Pernambuco (Pacto Pela Vida).

\author{
Institucionalização \\ do Sistema Nacional \\ de Informações de \\ Segurança Pública, \\ Prisionais e sobre \\ Drogas (Sinesp) (2012)
}

Fonte: Elaboração própria. 


\section{NOTA DE AGRADECIMENTO}

Texto inicialmente elaborado sob encomenda do Centro de Pesquisas Jurídicas Aplicadas da Escola de Direito da Fundação Getulio Vargas. Agradecemos a leitura e os comentários de todos que participaram do workshop de discussão realizado pelo CPJA, em 2013, em especial de José Reinaldo Lima Lopes, Eduardo Pannunzio e Fernanda Meirelles Ferreira.

\section{REFERÊNCIAS BIBLIOGRÁFICAS}

ADORNO, Sérgio. Lei e ordem no segundo governo FHC. Tempo Social, São Paulo, v. 15, n. 2, p. 103 40, nov. 2003.

ANISTIA INTERNACIONAL BRASIL. "Eles entram atirando": policiamento de comunidades socialmente excluídas. Rio de Janeiro, 2005. Disponível em: <http://www.prsp.mpf.mp.br/prdc/areadeatuacao/ torviolpolsist/Anistia\%20Internacional\%20-\%20Eles\%20entram\%20atirando\%20-\%20versao\%20basica. pdf>. Acesso em: 16 jan. 2016.

"Entre o ônibus em chamas e o caveirão": em busca da segurança cidadã. Rio de Janeiro, 2007. Disponível em: <http: / /www.amnesty.org/es/library/asset/AMR19/010/2007/es/19b53e10d39c-11dd-a329-2f46302a8cc6/amr190102007pt.pdf>. Acesso em: 16 jan. 2016.

ANISTIA INTERNACIONAL. Informe 2010: O estado dos direitos humanos no mundo. Londres, 2010. Disponível em: <http://brasil.indymedia.org/media/2010/05//472198.pdf>. Acesso em: 16 jan. 2016.

AZEVEDO, Rodrigo Guiringuelli. Tendências do controle penal na modernidade periférica: as reformas penais no Brasil e na Argentina na última década. 2003. Tese (Doutorado em Sociologia) - Universidade Federal do Rio Grande do Sul, Porto Alegre, 2003.

Informalização da justiça e controle social: estudo sociológico da implantação dos Juizados Especiais Criminais em Porto Alegre. São Paulo: IBCCrim, 2000.

BIDERMAN, Ciro; BUENO, Samira; LIMA, Renato Sergio de; SCHNEIDER, Alexandre. Pax Monopolista and Crime: the Case of the Emergence of the Primeiro Comando da Capital in São Paulo. No prelo. 
BONELLI, Maria da Glória. Profissionalismo e política no mundo do direito: as relações dos advogados, desembargadores, procuradores de justiça e delegados de polícia com o Estado. São Carlos: Edufscar; Sumaré, 2002.

BUENO, Samira. Letalidade na ação policial. In: LIMA, Renato S. de; RATTON, José Luiz; AZEVEDO, Rodrigo G. (Orgs.). Crime, polícia e justiça no Brasil. São Paulo: Contexto, 2014.

CALDEIRA, Teresa Pires do Rio. Cidade de muros: crime, segregação e cidadania em São Paulo. São Paulo: Edusp; Ed. 34, 2000.

CARVAlho, José Murilo de. Cidadania no Brasil: o longo caminho. Rio de Janeiro: Civilização Brasileira, 2002.

CERQUEIRA, Daniel. Mapa de homicídios ocultos no Brasil. Texto para Discussão 1848, Brasília, DF, Instituto de Pesquisa Econômica Aplicada (Ipea), jul. 2013.

CÂMARA DOS DEPUTADOS. Comissão parlamentar de inquérito sobre organizações criminosas do tráfico de armas. Brasília, DF, nov. 2006.

COSTA, Arthur Trindade Maranhão da. Estado, polícia e democracia. 2003. Tese (Doutorado em Sociologia) - Universidade de Brasília, Brasília, 2003.

DaMATTA, Roberto. Carnavais, malandros e heróis: para uma sociologia do dilema brasileiro. Rio de Janeiro: Zahar, 1979.

DEBERT, Guita Grin; GREGORI, Maria Filomena; PISCITELLI, Adriana. Gênero e distribuição da justiça: as Delegacias de Defesa da Mulher e a construção das diferenças. Campinas: Unicamp; Pagu - Núcleo de Estudos de Gênero, 2006. (Coleção Encontros).

DIAS NETO, Theodomiro. Segurança urbana: o modelo da nova prevenção. São Paulo: Revista dos Tribunais; Fundação Getulio Vargas, 2005.

FERREIRA, Sinésio Pires; LIMA, Renato Sérgio de; BESSA, Vagner. Criminalidade violenta e homicídios em São Paulo: fatores explicativos e movimentos recentes. Coleção Segurança com Cidadania, Brasília, v. 1, n. 3, ano 1, p. 11-20, 2009.

FÓRUM BRASILEIRO DE SEGURANÇA PÚBLICA (FBSP). Anuário Brasileiro de Segurança pública. Edição VIII. São Paulo, 2014. 
HUMAN RIGHTS WATCH. Police Brutality in Urban Brazil. Nova York, 1997.

. Força Letal. Violência Policial e Segurança Pública no Rio de Janeiro e em São Paulo. Nova York, 2009.

IGARAPÉ. Violencia, drogas y armas: ¿Otro futuro posible?. Rio de Janeiro, mar. 2013.

IZUMINO, Wânia Pasinato. Delegacias de Defesa da Mulher e Juizados Especiais Criminais: contribuições para a consolidação de uma cidadania de gênero. Revista Brasileira de Ciências Criminais, ano 10, n. 40, p. 282-295, out.-dez. 2002.

KANT DE LIMA, Roberto. A polícia da cidade do Rio de Janeiro: seus dilemas e paradoxos. Rio de Janeiro: Forense, 1995.

Direitos civis e direitos humanos: uma tradição judiciária pré-republicana? São Paulo em Perspectiva, v. 18, n. 1, p. 49-59, 2004.

LIMA, Renato Sérgio de. Conflitos sociais e criminalidade urbana: uma análise dos homicídios cometidos no Município de São Paulo. São Paulo: Sicurezza, 2002. v. 1.

. Contando crimes e criminosos em São Paulo: uma sociologia das estatísticas produzidas e utilizadas entre 1871 e 2000. 2005. Tese (Doutorado em Sociologia) - Faculdade de Filosofia, Letras e Ciências Humanas, FFLCH-USP, São Paulo, 2005.

Segurança pública e os 20 anos da Constituição Cidadã. Cadernos ADENAUER, São Paulo, v. 1, p. 75-84, 2008.

Entre palavras e números: violência, democracia e segurança pública no Brasil. São Paulo: Alameda, 2011.

; SINHORETTO, Jacqueline. Qualidade da democracia e polícias no Brasil. In: LIMA, Renato Sérgio de (Org.). Entre palavras e números: violência, democracia e segurança pública no Brasil. São Paulo: Alameda, 2011.

; SINHORETTO, Jacqueline; ALMEIDA, Frederico de. Entre advogados e policiais: opiniões dos operadores da justiça paulista sobre política criminal. In: XIV Congresso Brasileiro de Sociologia, Rio de Janeiro: Sociedade Brasileira de Sociologia, 2009. p. 270.

; COSTA, Arthur Trindade Maranhão da. Segurança pública. In: LIMA, Renato S. de; RATTON, 
José Luiz; AZEVEDO, Rodrigo G. (Orgs.). Crime, polícia e justiça no Brasil. São Paulo: Contexto, 2014.

LOCHE, Adriana. A letalidade de ação policial: parâmetros para análise. Tomo - Revista do Núcleo de Pós-Graduação e Pesquisa em Ciências Sociais. São Cristóvão-SE, NPPCS/UFS, n. 17 jul./dez., 2010.

MINGARDI, Guaracy. Tiras, gansos e trutas: cotidiano e reforma na Polícia Civil. São Paulo: Scritta, 1992.

MISSE, Michel. Malandros, marginais e vagabundos: a acumulação social da violência no Rio de Janeiro. 1999. Tese (Doutorado em Sociologia) - Instituto Universitário de Pesquisas do Rio de Janeiro (Iuperj), Rio de Janeiro, 1999.

MUNIZ, Jacqueline de Oliveira; ZACCHI, José Marcelo. Avanços, frustrações e desafios para uma política progressista, democrática e efetiva de segurança pública no Brasil. São Paulo: Fundação Friedrich Ebert Stiftung, 2004. (Textos Prosur/Segurança Cidadã).

NASCIMENTO, Andréa Ana do. A profissionalização e especialização da Polícia Civil no Estado do Rio de Janeiro. In: XIV Congresso Brasileiro de Sociologia, GT Ocupações e Profissões, 2009.

ORGANIZAÇÃO DAS NAÇÕES UNIDAS (ONU). Report of the Special Rapporteur on extrajudicial, summary or arbitrary executions. Philip Alston. Nova York, 2010.

Promoção e proteção de todos os direitos humanos, civis, econômicos, sociais e culturais incluindo o direito ao desenvolvimento: relatório do Relator Especial de execuções extrajudiciais, sumárias ou arbitrárias, dr. Philip Alston. Nova York, 2007.

PAIXÃO, Antônio Luiz. A organização policial numa área metropolitana. Dados - Revista de Ciências Sociais, v. 25, n.1, p. 63-85, 1982.

Crimes e criminosos em Belo Horizonte, 1932-1978. In: PINHEIRO, P. (Org.). Crime, violência e poder. São Paulo: Brasiliense, 1983. p. 11-44.

PONCIONI, Paula. Tornar-se policial: a construção da identidade profissional do policial do estado do Rio de Janeiro. 2004. Tese (Doutorado em Sociologia) - Faculdade de Filosofia, Letras e Ciências Humanas, FFLCH-USP, São Paulo, 2004.

PROENÇA, Domênico Proença; MUNIZ, Jacqueline; PONCIONI, Paula. Da governança de polícia à governança policial: controlar para saber, saber para governar. Revista Brasileira de Segurança Pública, v. 5, p. 14-50, 2009. 
ROSE, Nikolas. Powers and Freedom: reframing political thought. United Kingdom: Cambridge University Press, 1999.

SANTOS, Wanderley Guilherme dos. Cidadania e justiça: a política social na ordem brasileira. 2. ed. Rio de Janeiro: Campus, 1987.

SILVA, Cátia Aida. A disputa pela jurisprudência na área da infância: promotores, juízes e adolescentes infratores. In: XX Reunião Anual da ANPOCS, Caxambu-MG, 22-26 out. 1996.

SINHORETTO, Jacqueline. Ir aonde o povo está: etnografia de uma reforma da justiça. 2007. Tese (Doutorado em Sociologia) - Faculdade de Filosofia, Letras e Ciências Humanas, FFLCH-USP, São Paulo, 2007.

SPAGNOL, Antônio Sérgio. Garotos perdidos: um estudo sobre os jovens delinquentes na cidade de São Paulo. 2003. Tese (Doutorado em Sociologia) - Faculdade de Filosofia, Letras e Ciências Humanas, FFLCH-USP, São Paulo, 2003.

SOU DA PAZ. Diagnóstico dos homicídios na cidade de São Paulo: análise das ocorrências registradas entre janeiro de 2012 e junho de 2013. São Paulo, dez. 2013.

TAVARES DOS SANTOS, José Vicente. Violências e conflitualidades. Porto Alegre: Tomo, 2009.

;TIRELLI, Cláudia. A ordem pública e o ofício de polícia: a impunidade na sociedade brasileira. In: SOUSA, Luís André de (Org.). Psicanálise e colonização: leituras do sintoma social no Brasil. Porto Alegre: Artes e Ofícios, 1999. p. 113-127.

VASCONCELLOS, Fernanda Bestetti. A prisão preventiva como mecanismo de controle e legitimação do campo jurídico. 2008. Dissertação (Mestrado em Ciências Sociais) - Faculdade de Filosofia e Ciências Humanas, PUC-RS, Porto Alegre, 2008.

ZAVERUCHA, Jorge. Democracia e instituições políticas brasileiras no final do século XX. Recife: Bagaço, 1998. 
ESTADO, POLÍCIAS E SEGURANÇA PÚBLICA NO BRASIL : $8 \mathbf{5}$

Renato Sérgio de Lima

Doutor EM SOCIOLOGIA PELA USP.

PROFESSOR DA EAESP-FGV.

VICE-PRESIDENTE dO Fórum BRASILEIRO

de Segurança Pública.

r.rsdlimadagmail.com

Samira Bueno

Doutoranda em Administração Pública E Governo NA EAESP-FGV.

DiRetora executiva do Fórum Brasileiro

de Segurança Pública.

samibuenodamail.com

Guaracy Mingardi

Doutor em Ciência Política Pela USP e membro do Fórum Brasileiro de Segurança Pública.

guaracymaterra.com.br 